\title{
THE CLASSICISM OF HUGH TREVOR-ROPER
}

\author{
S. J. V. Malloch* \\ University of Nottingham, U.K.
}

\begin{abstract}
Hugh Trevor-Roper was educated as a classicist until he transferred to history, in which he made his reputation, after two years at Oxford. His schooling engendered in him a classicism which was characterised by a love of classical literature and style, but rested on a repudiation of the philological tradition in classical studies. This reaction helps to explain his change of intellectual career; his classicism, however, endured: it influenced his mature conception of the practice of historical studies, and can be traced throughout his life. This essay explores a neglected aspect of TrevorRoper's intellectual biography through his 'Apologia transfugae' (1973), which explains his rationale for abandoning classics, and published and unpublished writings attesting to his classicism, especially his first publication 'Homer unmasked!' (1936) and his wartime notebooks.
\end{abstract}

When the young Hugh Trevor-Roper expressed a preference for specialising in mathematics in the sixth form at Charterhouse, Frank Fletcher, the headmaster, told him curtly that 'clever boys read classics'. ${ }^{1}$ The passion that he had already developed for Homer in the under sixth form spread to other Greek and Roman authors. In his final year at school he won two classical prizes and a scholarship that took him in 1932 to Christ Church, Oxford, to read classics, literae humaniores, then the most

\footnotetext{
* Department of Classics, University of Nottingham, NG7 2RD.

It was only by chance that I developed an interest in Hugh Trevor-Roper: in 2010 I happened upon his Letters from Oxford in a London bookstore and, reading them on the train home, was captivated by the world they evoked and the style of their composition. Blair Worden, Trevor-Roper's literary executor, encouraged this interest, and kindly gave me permission to consult the Dacre Archive at Christ Church, Oxford. There Judith Curthoys has been immensely helpful in guiding me through the collection and supplying me with materials at a distance. Earlier versions of this essay were presented in St Andrews and Bristol and discussed afterwards to my profit. I am grateful too for the feedback that I have received from P. Garnsey, J. Howard-Johnston, R. Osborne, M. D. Reeve, C. Stray, and B. Worden, and from the advice of the editors and readers of the CCJ.
}

1 '[Ch.] 5 Charterhouse', in 'Memoirs chs 1-7', p. $\lambda$ (Soc. Dacre 6/34/2). 
prestigious honours degree in the university. ${ }^{2}$ There he would win the Hertford and Craven scholarships and earn a first in Honour Moderations in 1934. 'A glittering career as a classicist awaited' him, in the words of Blair Worden in his fine biographical essay. ${ }^{4}$ Then a change took place: Trevor-Roper switched from classics to modern history, which in Oxford started with the middle ages. He graduated with first-class honours in 1936 and was elected to a Junior Research Fellowship at Merton the following year and to a Studentship in Modern history at Christ Church after the war. His career as an historian was by then secure, and international renown would soon follow with the publication of The Last Days of Hitler in 1947.

What had happened to drive Trevor-Roper from classics? He reflected publicly on this question in his address as President-elect of the Joint Association of Classical Teachers in May 1973. This 'Apologia transfugae'5 was delivered at a time when J. E. Sharwood Smith, the editor of Didaskalos (the Proceedings of JACT), was interested in receiving submissions reflecting on the future of classics from scholars outside the discipline. It is unclear whether Trevor-Roper's choice of subject was affected by such external considerations, but Sharwood Smith wrote that the 'Apologia' 'brilliantly fulfilled at least one purpose of the projected series, namely to help us see ourselves as others see us ${ }^{6}{ }^{6}$ Trevor-Roper in fact offered the perspective of a former insider. His 'Apologia' sketches the place of classics in Britain and Germany since the eighteenth century and the preoccupations of prominent scholars that influenced the study of classics in his time as an undergraduate. Despite his passion for ancient literature, he was driven from classics by what he saw as scholars' narrow obsession with textual criticism, a 'parlour game' he considered pointless. Hope, he asserted, lay with scholars who were illuminating the ancient world with the aid of methodologies imported from outside disciplines. Among them, Moses Finley was Trevor-Roper's favourite.

\footnotetext{
2 Stray (1998) 282; Currie (1994) 110-11.

${ }^{3}$ In 1932/33 Trevor-Roper earned an honourable mention for the Gaisford Prize for Greek verse composition (Oxford University gazette 63 (1932-33) 578). In his second year, 1933/34, he repeated this distinction in the competition for the Gaisford Prize and won the Craven and Hertford scholarships (Oxford University gazette 64 (1933-34) 290, 701, 722). After switching to history he won the Ireland scholarship and was proxime accessit in the Gaisford Prize for Greek verse composition: see below section V. In a late interview with Frank Johnson, Trevor-Roper remarked, 'I was regarded, I am told, as the best classical scholar in my year' (transcript at Soc. Dacre 6/34/4).

${ }^{4}$ Worden (2007) 249.

5 'Apologia Transfugae' was first published, in 'slightly abbreviated' form, in The Spectator in 1973 (see below section IV) and in Didaskalos the following year (Trevor-Roper (1974)). The typescript is in the Dacre Archive at Soc. Dacre 2/1/36.

${ }^{6}$ Sharwood Smith (1974) 391.
} 
The address created a small sensation in the world of classical studies. TrevorRoper's view of the discipline was dramatically misconstrued by the Times Educational Supplement and provoked criticism from his old friend Hugh LloydJones, Regius Professor of Greek at Oxford since 1960. The 'Apologia' and its reception open a window on tensions within the discipline about how classical scholarship should be conducted, and it offers insights along the way into TrevorRoper's priorities as an historian. The picture is filled out by his other writings, published and unpublished, which supply contexts on both sides of his time as an undergraduate. For the earlier period, they reveal the origins of his love of ancient literature and the narrow limits of his schooling in classics. For the latter, they demonstrate an enduring classicism that was central to his intellectual life as he was crafting an identity as an historian. Peter Ghosh, in a stimulating essay on TrevorRoper's engagement with the history of ideas, has written that 'the starting point for our understanding of the mind and achievement of Hugh Trevor-Roper must lie in the years between 1945 and 1957'.7 A study of Trevor-Roper's classical interests reveals that the decisive formation came earlier. ${ }^{8}$ His classicism was characterised by a love of Greek and Latin language and literature. It was a distinctive classicism, since it rested on a repudiation of the narrow philological focus of classical scholarship that was conventional at the time. That reaction helps to explain Trevor-Roper's change of intellectual career. But it did not end his classicism. The attitude to classics which he worked out for himself would be absorbed into his mature conception of the practice of historical studies, and his love of classical literature would endure throughout his life.

\footnotetext{
${ }^{7}$ Ghosh (2011) 502. Ghosh, it should be said, was reacting against an emphasis on a transition in Trevor-Roper's thinking in a still later period, the 1960s (489). Ghosh uses the term 'classicism' of Trevor-Roper at 494 n.133. He chastises Adam Sisman, Trevor-Roper's biographer, for ignoring Trevor-Roper's classicism but largely ignores it himself (cf. 504).

${ }^{8}$ Ghosh (2011: 488; cf. 504) rightly emphasises the importance of the essay to Trevor-Roper's practice as an historian, and draws an acute parallel with the Contributi of the ancient historian Arnaldo Momigliano, whose Visiting Fellowship at Peterhouse under Trevor-Roper's Mastership was one expression of their intellectual affinities. When Ghosh suggests (489) that Trevor-Roper's Historical Essays (= 1957a) are 'by far the best guide to the evolution of his mind at the time' (i.e. 1945-57), he misses the significance of 'The World of Homer', which illustrated an abiding interest from his school days.
} 
Trevor-Roper takes the audience of his 'Apologia' of 1973 back to his undergraduate days in the 1930s. Memoirs composed at the end of his life and left unpublished at his death supply impressions of a school and university education that established his passion for classics and revealed the sometimes narrow and complacent approach of his educators. They also reveal factors omitted from the 'Apologia' that influenced his decision to switch to history.

English public schools flourished in the nineteenth century on the back of the social aspirations of an increasingly wealthy middle class. Education was regarded as a marker of social status, and the cultural authority of classics ensured that it was considered the fundamental educational ingredient in the creation of the manners and style of a gentleman. From the later nineteenth century onwards, challenges to the permanency and universality of classics from many directions - the rise of vernacular studies, historicism, natural science - undermined its cultural primacy, and gradually it became only one of many competing 'disciplines'. But classics, and in particular Latin, remained strongly embedded in the curriculum of the public schools, and a public school education remained appealing to middle-class parents with social aspirations. $^{9}$

One such parent was Trevor-Roper's mother Kathleen. She was determined to send her children to good schools, a 'social necessity', in Trevor-Roper's words, 'if one was to keep one's place in the social hierarchy', although she knew nothing of them. ${ }^{10}$ At the first, Belhaven Hill, which Trevor-Roper entered in 1924 aged ten, he was thoroughly drilled in the classical languages by Wilfred Ingham, or Bungey as he was called because of his springing step. ${ }^{11}$ One of the two founders of Belhaven, Bungey seemed a living embodiment of Victorian and Edwardian schoolmasterly eccentricity. He 'had some hobby horses which he would ride, with whip and spur', remembered Trevor-Roper in old age :

One of them was 'dative verbs'. Dative verbs are verbs which, in the Latin language, recognise the dative, not the accusative case in the nouns which they govern. They also have some other incidental eccentricities. Bungey could not mention dative verbs without making a human parallel and then launching into a diatribe against it. Dative verbs, he would declare,

\footnotetext{
${ }^{9}$ Stray (1998) 180, 183-87, 200, 231, 259-60.

${ }^{10}$ Quotation: '[Ch.] 3 Glanton to Alnwick/ Stancliffe', in 'Memoirs chs 1-7' , p. G (Soc. Dacre 6/34/2). Mother's lack of knowledge: '[Ch.] 4 Belhaven Hill', in 'Memoirs chs 1-7', p. ל.

${ }^{11}$ Sisman (2010) 13. Trevor-Roper claims to have been taught Latin and Greek well by Bungey: '[Ch.]

5 Charterhouse', in 'Memoirs chs 1-7', p. v (Soc. Dacre 6/34/2).
} 
are tiresome, wayward, eccentric, unpredictable verbs which will not conform to the rational rules accepted by their verbal colleagues but insist on going their own way, just like certain persons who always try to be different thus causing unnecessary difficulties in a well-ordered society... and then he would be off, unstoppable, far from the set course, denouncing human dative verbs, sometimes, I felt, with a staring eye on me. ${ }^{12}$

It was a measure of the narrowness of language-learning at Belhaven that when Trevor-Roper borrowed Mommsen's History of Rome from the school library, he was judged by Bungey to have taken his 'zeal for learning too far'. ${ }^{13}$ But Bungey, staring eye or not, was fond of Trevor-Roper and held him up to his classmates as a model. ${ }^{14}$ Trevor-Roper flourished at Belhaven, and in 1927, aged 13, he successfully sat for a scholarship to Charterhouse. ${ }^{15}$

With its strong classical tradition, Charterhouse established Trevor-Roper's love of classical literature by broadening his reading. In the under sixth form he specialised in classics, which he was to read to "learn the language and appreciate the style'. ${ }^{16}$ Frank Fletcher introduced him to 'the three greatest of Greek poets - Homer, Aeschylus, and Pindar - and the greatest of the Roman historians, Tacitus' ${ }^{17}$ Homer and Aeschyus were the great revelations. Trevor-Roper's progress in reading Homer had been slow until his vocabulary 'broke in my hands' as he read the description of the Gardens of Alcinous in Odyssey 7 (112-32). ${ }^{18}$ Thereafter he could read the poem 'freely and easily and enjoy it'. ${ }^{19}$ In his wartime notebooks Trevor-Roper reflected on the experience under a rubric that described the 'memorable moments' in his life up to c. 1940. There he remarks that he had 'never wavered' in his 'passion' for Homer since, ${ }^{20}$ and in a later memoir he confirmed that the experience converted him into a 'passionate classicist': '[i]t was a revelation to me', he continues, 'I have always agreed with Walter Bagehot that "a man who has never read Homer is like a man who has never seen the sea: there is a great object of which he is unaware". ${ }^{21}$ All his life

\footnotetext{
12 '[Ch.] 4 Belhaven Hill', in 'Memoirs chs 1-7', p. $\gamma$ (Soc. Dacre 6/34/2).

${ }^{13}$ Sisman (2010) 15.

${ }^{14}$ Sisman (2010) 13.

${ }^{15}$ Sisman (2010) 15.

16 '[Ch.] 6 Christ Church', in 'Memoirs chs 1-7', p. 9 (Soc. Dacre 6/34/2).

17 '[Ch.] 5 Charterhouse', in 'Memoirs chs 1-7', pp. $\mu-v$ (Soc. Dacre 6/34/2).

${ }^{18} \mathrm{He}$ described the moment at (1974) 402.

${ }^{19}$ Trevor-Roper (2015) 40, where the book and scene of the Odyssey are specified.

${ }^{20}$ Trevor-Roper (2015) 40.

21 '[Ch.] 5 Charterhouse', in 'Memoirs chs 1-7', p. v (Soc. Dacre 6/34/2); cf. Trevor-Roper (2015) 30. Walter Bagehot $((1858) 46=(1879) 1.255)$ had written, 'For the English, after all, the best literature is
} 
he knew long passages of Homer by heart. But the 'greatest discovery' of that period, as Trevor-Roper would remark in the 'Apologia', was 'the Aeschylus of the Suppliant Women, of the Seven against Thebes, and, above all, of the Oresteia, with his vivid, highly charged, complicated metaphors, swollen to bursting by the pressure of tormenting thought'. ${ }^{22}$ Image and metaphor were central to Trevor-Roper's appreciation of classical literature and style. ${ }^{23}$

This expansion in Trevor-Roper's life of reading and study was counterbalanced by the narrow complacency of several of his classics teachers at school and university. Their style would come to characterise classical education in his mind. A. L. Irvine (1881-1967), a Wykehamist and scholar of Christ Church, had been teaching classical and English literature at Charterhouse since $1914 .{ }^{24}$ He prided himself on being a 'full man':

Irvine's ideal was 'the scholar and the gentleman' who had absorbed classical and English literature and some decorative learning and who derived pleasure from it, and he introduced his pupils to these pleasures, but any suggestion that there was a world - whether of literature or of thought - outside those limits was inadmissible to him. He did not encourage exploration beyond the frontiers of the fair domain which he had acquired, or doubt within it. ${ }^{25}$

The undeveloped taste of the schoolboy no doubt benefited from such instruction, which he could gradually shed as he acquired his own tastes and feelings; but the danger of Irvine's method, as Trevor-Roper reflected in his wartime notebook in 1942, was that the finality of his pronouncements might discourage 'all further experiment'. ${ }^{26}$

At Christ Church, Trevor-Roper's tutor J. B. Barrington-Ward (1894-1946) offered a variation of the narrowness of Irvine of Charterhouse:

he was interested in the classics not, in the humanist tradition, as presenting an exemplary model of life, nor as a means of understanding the whole civilisation and culture of antiquity -

\footnotetext{
the English... Of course, a man who has not read Homer is like a man who has not seen the ocean. There is a great object of which he has no idea. But we cannot be always seeing the ocean...'.

22 Trevor-Roper (1974) 402.

${ }^{23}$ See further below section $\mathrm{V}$.

${ }^{24}$ On Irvine see Todd (2004) 2.498-99 (H. Picarda).

25 '[Ch.] 5 Charterhouse', in 'Memoirs chs 1-7', pp. v-o (Soc. Dacre 6/34/2); cf. Trevor-Roper (2015) 70.

${ }^{26}$ Trevor-Roper (2015) 40.
} 
what Germans call Altertumswissenschaft - but as an area of knowledge in which one could enjoy playing learned and arcane parlour-games. ${ }^{27}$

Such 'parlour games' were the practices of composition, translation, and textual criticism that 'Mods dons' of that period such as Barrington-Ward conducted on a narrow range of classical texts that were not seriously studied as literature. ${ }^{28}$ Barrington-Ward stood in contrast to another of Trevor-Roper's tutors, D. L. Page (1908-1978), a 'true scholar', ${ }^{29}$ who would go on to a distinguished career in Cambridge as Regius Professor of Greek and Master of Jesus College, and make major contributions to the study of Greek poetry. ${ }^{30}$

Trevor-Roper's late memoirs confirm the claim of his 'Apologia' that the narrowness of classical studies drove him to study history. They demonstrate too that he made the change also with a mind to his career. Offers from relatives to take up positions in a solicitors' office in Manchester or in the family firm in South America appealed less than the prospect of being a teacher. But he decided that teaching history would be more rewarding than 'teaching composition in the [ancient] languages and in tinkering with texts', pursuits which took up 'too much of the time and energy of classical teachers'. ${ }^{31}$

III

Trevor-Roper commenced his 'Apologia' with an account of humanism, a term he proposed to use in its 'correct and original sense: the study of Literae humaniores, human as distinct from divine texts, Homer and Virgil, not Scripture and the Fathers' ${ }^{32}$ Despite rejection of its doctrine by Enlightenment thinkers, humanism

\footnotetext{
27 '[Ch.] 6 Christ Church', in 'Memoirs chs 1-7', p. 3. Barrington-Ward played the game to the extent that he confused his own hexameters with Virgil's: Trevor-Roper (2015) 54; cf. (1991) 64.

${ }^{28}$ See Nisbet (2007) 219-20; Russell (2007) 229-32. Did Donald Russell (237) have Trevor-Roper in mind, inter alios, when he remarked of the late 1950s that '...there were still people around - both within and perhaps even more outside Lit. Hum. - for whom the subspecies Mods don was an inferior breed, not up to handling the mature minds and capable only of donnish games and a sort of sophisticated proof-reading'?

29 '[Ch.] 6 Christ Church', in Memoirs chs 1-7', p. 3.

${ }^{30}$ For Page see Lloyd-Jones (1982a) 295-304; Briggs and Calder (1990) 353-60 (R. Dawe); Todd (2004) 3.736-37 (R. Renehan). Trevor-Roper would also work with Page in military intelligence during the war: Trevor-Roper (2014b) 38, 156.

31 '[Ch.] 6 Christ Church', in 'Memoirs chs 1-7', p. 10.

32 Trevor-Roper (1974) 393. Trevor-Roper observed in the same context that the term had since lost its specificity: 'The trouble is...that this simple distinction, which served to describe all knowledge in the
} 
'clung' to the centre of education in eighteenth- and nineteenth-century Britain and Europe. ${ }^{33}$ Trevor-Roper marvelled at the contradiction that the industrial revolution was advanced by elites in Britain who were reared on the literature of a 'city-state and empire' whose slave-owning ruling classes regarded industry and commerce as essentially 'vulgar'. ${ }^{34}$ In the Germany of the nineteenth century the claims of classical scholarship were 'higher and more pretentious', and even more paradoxical. ${ }^{35}$ In Britain classics could be recommended as the literature of liberty, of equality among free citizens. That was possible in the Germany of the early nineteenth century, but after 1850 humanism had to be adapted to a society that was industrialised and opposed to the doctrines of the Hellenism which it openly expressed. Yet the 'absurd' claim of continuity was upheld: German historians could see eighteenth-century Germany as the new Greece, the empire of Bismarck as the new Rome. ${ }^{36}$ How could such a contradiction be maintained? Trevor-Roper argued that the 'figment' that modern society represented classical values could only be upheld through hypocrisy or by narrowing classical studies to language or literature and divorcing texts from their contexts. The Victorians were 'expert in the necessary hypocrisy': 'Just as they could scientifically destroy the intellectual basis of Christianity and yet ceremoniously assert, and evidently believe, the truth of the same Christianity, so they were perfectly capable of looking at the literature of Antiquity and not seeing what was plainly there' ${ }^{37}$ In Germany scholars took refuge in technical expertise. They edited and emended texts and claimed 'for this narrow field of erudition, a moral and intellectual superiority almost directly proportionate to its narrowness' ${ }^{38}$ This philological approach committed a grave sin: it divorced literature from the society which produced it and which it reflected.

sixteenth century, is now less comprehensive...other branches of science have shot out and flowered' (393). Hence his description of Samuel Johnson's advocacy of a 'literary over a scientific education' as 'the old claim for a humane, if not necessarily for a humanist, education' (411-12); his own support of classics as part of such education (412); and his later hope that 'I would like classical studies to be restored to their position as a humanist education' (Trevor-Roper to J. Shiel, 21 January $1992=$ TrevorRoper (2014a) 382). According to Ghosh (2011: $490 \mathrm{n}$. 84), Trevor-Roper generally 'had little interest in humanism in the strict, Renaissance sense' (ie. the 'correct and original sense'), and 'always used the term "humanist" so as to combine the early modern idea of humanists as scholars and the mid-20th century meaning which focussed on man as the centre of the moral universe'.

${ }^{33}$ Trevor-Roper (1974) 394.

${ }^{34}$ Trevor-Roper (1974) 396.

${ }_{35}$ Trevor-Roper (1974) 397.

${ }^{36}$ Trevor-Roper (1974) 397-98.

${ }^{37}$ Trevor-Roper (1974) 398.

${ }^{38}$ Trevor-Roper (1974) 399. 
Trevor-Roper's classical education grew out of this nineteenth-century background. In the second part of his 'Apologia' he articulated the basis of his reaction to it. The narrowness that characterised the Germanic approach to the study of classics was embodied for him in 'two grim, frowning faces' that emerged from 'the semi-Freudian fog' hanging before his eyes:

the remote, patrician visage of the Teutonic Knight Ulrich von Wilamowitz-Moellendorf; then, behind him, longo intervallo, the sour, crabbed face of the spent English poet, A. E. Housman. $^{39}$

Trevor-Roper believed Wilamowitz (1848-1931) symbolised the 'barrenness' of a purely literary and philological approach to classical literature that led 'nowhere' and 'the absurd pretentiousness of assuming that so narrow an approach can have any wider meaning' ${ }^{40}$ Housman (1859-1936) offered the 'same warning' on native soil. Trevor-Roper was alarmed at the 'outdated incivilities' of his preface to Manilius that were so reminiscent of the 'obscene pedants of the seventeenth century' and at his article in Hermes 'consisting of a series of texts on sexual perversions which he evidently saw some reason to list but not to explain'. ${ }^{41}$ He struggled to recognise in this scholarship the poet of A Shropshire Lad and the Last Poems, ${ }^{42}$ and 'felt no temptation to submit to the same desiccating process'. ${ }^{43}$

Wilamowitz and Housman represented a tradition that ultimately alienated Trevor-Roper. His first response, however, was different. He conceded that when he

\footnotetext{
${ }^{39}$ Trevor-Roper (1974) 400. Louis Macneice remembered Wilamowitz as one of the classical 'gods' of his undergraduate days at Merton College, Oxford, in the late 1920s: 'And knowledge, besides, should be prized for the sake of knowledge:/ Oxford crowded the mantelpiece with gods -/ Scaliger, Heinsius, Dindorf, Bentley and Wilamowitz -/ As we learned our genuflexions for Honours Mods' (Autumn journal xiii). On Wilamowitz see Briggs and Calder (1990) 489-522 (R. Fowler). On Housman see Briggs and Calder (1990) 192-204 (P. Naiditch); Todd (2004) 2.477-80 (M. E. Irwin); Butterfield and Stray (2009).

40 Trevor-Roper (1974) 401.

${ }^{41}$ Trevor-Roper (1974) 401. Trevor-Roper was evidently referring to Housman (1931); cf. TrevorRoper (2015) 125. Housman did not introduce or conclude his discussion of the passages.

42 In March 1945, Trevor-Roper wrote, 'so I turn for relief [from the death of friends in war] to literature, and sometimes find my own condition there, elevated into a momentary sublimity by the magic art of Aeschylus, of Euripides, of Shakespeare, of Leopardi, of Housman, and of that brutal and lecherist old Psalmist-King' (Trevor-Roper (2015) 216). He later wrote that he admired Housman 'at one level' and disliked him 'intensely' at another (Trevor-Roper to A. Palmer, 2 November $1986=$ Trevor-Roper (2014a) 321). In a letter to Hugh Lloyd-Jones of 7 January 1982, Trevor-Roper remarked that he had 'recently re-read Housman's prefaces to Manilius, Lucan and Juvenal: they are dreadful!' (Soc. Dacre 1/3/30).

${ }^{43}$ Trevor-Roper (1974) 401-02. For a later assessment of Housman see Trevor-Roper to J. Shiel, 21 January 1992 = Trevor-Roper (2014a) 382.
} 
first started to read the Greek Tragedians he had marvelled at the brilliant textual criticism that secured the fame of Richard Bentley and Richard Porson and was continued, 'as a ritual exercise', in the pages of contemporary classical journals. ${ }^{44} \mathrm{He}$ tells how the undergraduate Thomas Gaisford (1779-1855) was informed that he could succeed as a scholar, if not as a gentleman, by editing a little-known Greek author. The merit of his edition of the Alexandrian grammarian Hephaestion put Gaisford on a path that saw him become Regius Professor of Greek, Canon of Durham, and Dean of Christ Church, and prompted his famous advice that the study of Greek 'not only elevates above the vulgar herd, but not infrequently leads to positions of considerable emolument' ${ }^{45}$ But, Trevor-Roper points out, Gaisford was an undergraduate in 1800: what was there to edit in 1934? His own narrow definition of classical literature at the time obscured the possibility of working on later authors, and he feared being reduced to the level of the two ancient grammarians who 'argued for a fortnight over the vocative of $e g o{ }^{\prime} .{ }^{46}$ Of course, broader vistas might have been opened up by the study of ancient history and philosophy in Greats, the second part of Literae humaniores. But, looking back, Trevor-Roper felt that the study of literature in isolation had closed his mind to its contexts, and he despaired of ancient history as it was then taught in Oxford, the pondering of 'textual cruces and speculative answers laboriously squeezed from the silence of partial sources or the gaps in Athenian tribute lists'. ${ }^{47}$ Trevor-Roper, bred on Gibbon and Gregorovius, longed for history with 'scope and sweep'. ${ }^{48}$ And so he transferred his course of studies to history, where under J. C. Masterman and Keith Feiling history was not allowed to become minute or scholastic or separated from literature and life. ${ }^{49}$

Trevor-Roper claimed that subsequent experience confirmed him in the rightness of his decision to abandon the formal study of classics. After switching to history he attended the seminars of Eduard Fraenkel (1888-1970), the refugee German

\footnotetext{
44 Trevor-Roper (1974) 409.

45 Trevor-Roper (1974) 403. Trevor-Roper quotes Gaisford from Tuckwell (1907) 124. For this advice see Stray (forthcoming).

46 Trevor-Roper (1974) 404. Trevor-Roper tentatively ascribes the story to Martianus Capella (also at (2015) 167). It occurs in Virgilius Maro Grammaticus, Epist. 2 (pp. 26-7 in Löfstedt's Teubner edition of 2003). For the limited range of classical texts studied in Oxford at the time cf. Nisbet (2007) 220.

${ }^{47}$ Trevor-Roper (1974) 404. Writing of the late 1940s at Oxford, Donald Russell (2007: 229) recalled 'with quite peculiar distaste' studying the Athenian tribute lists which were then 'very fashionable'.

48 Trevor-Roper (1974) 404.

49 Trevor-Roper (1974) 404-05.
} 
Professor who came to Oxford in 1934 and stayed at Christ Church in 1934/35. ${ }^{50}$ Trevor-Roper's impressions of Fraenkel's early period supply one example of what Mary Beard considers missing or underplayed in 'authorised' versions of Fraenkel's life, an exploration of the "awkward clash between the "myth" of German scholarship in the British imagination... and the real thing in the shape of a bona fide German professor, with his new-fangled ideas about seminars'. ${ }^{51}$ Trevor-Roper cared little for Fraenkel and his scholarship. He describes Fraenkel's 'magisterial authority' as a pupil of Wilamowitz, the deference he expected in return, and his ungrateful complaints to the Steward's office of Christ Church on seeing his accommodation for the first time: 'he forgot that he was an unexpected guest hospitably received and subsidized'. ${ }^{52}$ Trevor-Roper attributes Fraenkel's 'arrogance' not to his status as a German professor - for Einstein had recently arrived in Christ Church too, and he was a charmer - but to Fraenkel's being a classical scholar who had 'risen to eminence in the elitist temple of a pre-war German university'. ${ }^{53}$ According to Trevor-Roper, Fraenkel did not understand the university and college structures and treated in a 'somewhat summary fashion', as 'mere Privatdozenten', eminent scholars in their roles as college tutors. Trevor-Roper enjoyed the discomfiture of Maurice Bowra and his sort, but Fraenkel's method confirmed his 'prejudices' by reminding him of Wilamowitz and Housman. ${ }^{54}$

A later experience confirmed Trevor-Roper's sceptical opinion of the 'ingenious reconstructions' of textual critics. When, as a don, he had his writings typed out by a copyist, he noticed that the most common error involved jumping from one word to the same word a line or so later, 'omitting the intermediate text and thus making nonsense of the whole passage'. Trevor-Roper claimed that no amount of 'textual tinkering' could restore the original sense. Assuming that modern typists committed the same kinds of errors as medieval copyists of classical texts, he believed that 'such omissions are the cause of many corruptions in ancient manuscripts, and ingenious conjecture is effort wasted' ${ }^{55}$

\footnotetext{
${ }^{50}$ In Killcanon, room 1. On Fraenkel see Briggs and Calder (1990) 61-67 (N. Horsfall); Todd (2004) 1.334-37 (M. Deufert); Stray (2015).

${ }^{51}$ Beard (2013) 270 (= 'What gets left out', TLS 15 April 2005, a review of Todd (2004)).

52 Trevor-Roper (1974) 405.

${ }^{53}$ Trevor-Roper (1974) 405-06. For Fraenkel as a 'typical German professor' cf. West (2007) 210.

54 Trevor-Roper (1974) 409. Trevor-Roper was not alone in believing that Fraenkel did not understand how Oxford worked: cf. West (2007) 207. For Fraenkel's seminars cf. West 209-13.

55 Trevor-Roper (1974) 409. For Trevor-Roper's claim about this kind of error (which textual critics call saut du même au même) see Reeve (2011) 344.
} 
Trevor-Roper claimed that it was 'refreshing' to turn from 'textual pedantry' to consider the comparative methodologies which had 'recently' been imported into the discipline and were reviving it. ${ }^{56}$ He mentions a local example in E. R. Dodds' The Greeks and the irrational (1951), which drew on anthropology and sociology, and his outsider status in the frosty reception that he received from Oxford's classical establishment on his election as Regius Professor of Greek in $1936 .{ }^{57}$ His prime example was Moses Finley, another outsider, and his 'exciting' book The world of Odysseus, which appeared in 1955 and was hailed as provocative and original. ${ }^{58}$ But traditionalists, Trevor-Roper believed, would not have admitted 'frivolities' such as cultural history: when Eduard Fraenkel heard the word Geistesgeschichte, 'he declared summarily that Geistesgeschichte was merely a polysyllabical word for Quatsch' - a knowing variation on Housman's description of Überlieferungsgeschichte as a 'longer and nobler name than fudge'. 59

Trevor-Roper concluded his 'Apologia' on a positive note - 'as a lover of ancient literature, a believer in the teaching of classics' - with a defence of the value of a classical education. He believed that the 'rigour' of a discipline that 'imposes the necessity of understanding through a difficult medium' in 'an age of instant omniscience and journalistic slipslop' must be 'valuable'. ${ }^{60}$ More valuable, however, was the 'content and reward' of studying a different civilisation. Trevor-Roper regarded the acceptance that the ancient world was different from the modern as one of the great, salutary changes in contemporary classical education. ${ }^{61}$ Learning about a different civilisation, in his view, was a 'valuable lesson in objectivity, a warning against self-centred parochialism' ${ }^{62}$ He regarded the classical world as a justifiable object of study because 'it has something elevating to teach' and argued that the newfound autonomy of the modern from the ancient world was no reason for ignoring a

\footnotetext{
56 Trevor-Roper (1974) 409.

${ }^{57}$ Cf. Trevor-Roper to J. Shiel, 21 January 1992 = Trevor-Roper (2014a) 382. On the reaction to Dodds' appointment see Oxford DNB (H. Lloyd-Jones); Todd (2004) 1.248-9 (R. B. Todd). On Dodds see now Stray et al. (forthcoming).

${ }^{58}$ Cf. e.g. Stanford (1957); Hainsworth (1979). For a view from 2001 - 'The World of Odysseus can still be read for profit and for the reliable understanding of the "world" of the best two poems in the world's literature' - see Hornblower in Finley (2002) xxii.

59 Trevor-Roper (1974) 410; cf. Finley and Hopkins (2014) 183. For Housman on Überlieferungsgeschichte see (1926) xiii. The formulation was probably Trevor-Roper's, but Fraenkel did play with Housman's claim: see Reeve (2009) 141.

60 Trevor-Roper (1974) 410.

61 Trevor-Roper (1974) 408.

62 Trevor-Roper (1974) 410.
} 
civilisation that contributed so much to modern literature and thought. ${ }^{63}$ Finally, he rehearsed Samuel Johnson's support of a 'literary over a scientific education' in his Life of Milton: it amounted to the 'old claim for a humane, if not necessarily for a humanist [in the 'original and correct sense'], education' ${ }^{64}$ Trevor-Roper believed that the study of classical languages and literature had an important role to play in such an education by widening its base, deepening its foundations, and multiplying its rewards. A classical education might no longer be the end of wisdom, he concluded, but it was at least a beginning. ${ }^{65}$

The 'Apologia' had its characteristic moments of provocative mischief, and the provocation succeeded. The Times Educational Supplement splashed its front cover of 25 May 1973 with a cartoon by Richard Willson depicting Trevor-Roper destroying the Acropolis with a benign smile on his face. The caption read 'Professor Trevor-Roper laying about the classicists'.

Figure: Hugh Trevor-Roper 'laying about the classicists' 66

\footnotetext{
${ }^{63}$ Trevor-Roper (1974) 410-11.

${ }^{64}$ Trevor-Roper (1974) 411-12.

65 Trevor-Roper (1974) 412.

${ }^{66}$ Willson's cartoon originally appeared at TES 3026 (25 May 1973) 1, and is reprinted here by permission of the British Cartoon Archive at the University of Kent. I am grateful to Mark Bryant for his help in tracing the copyright of Willson's work.
} 


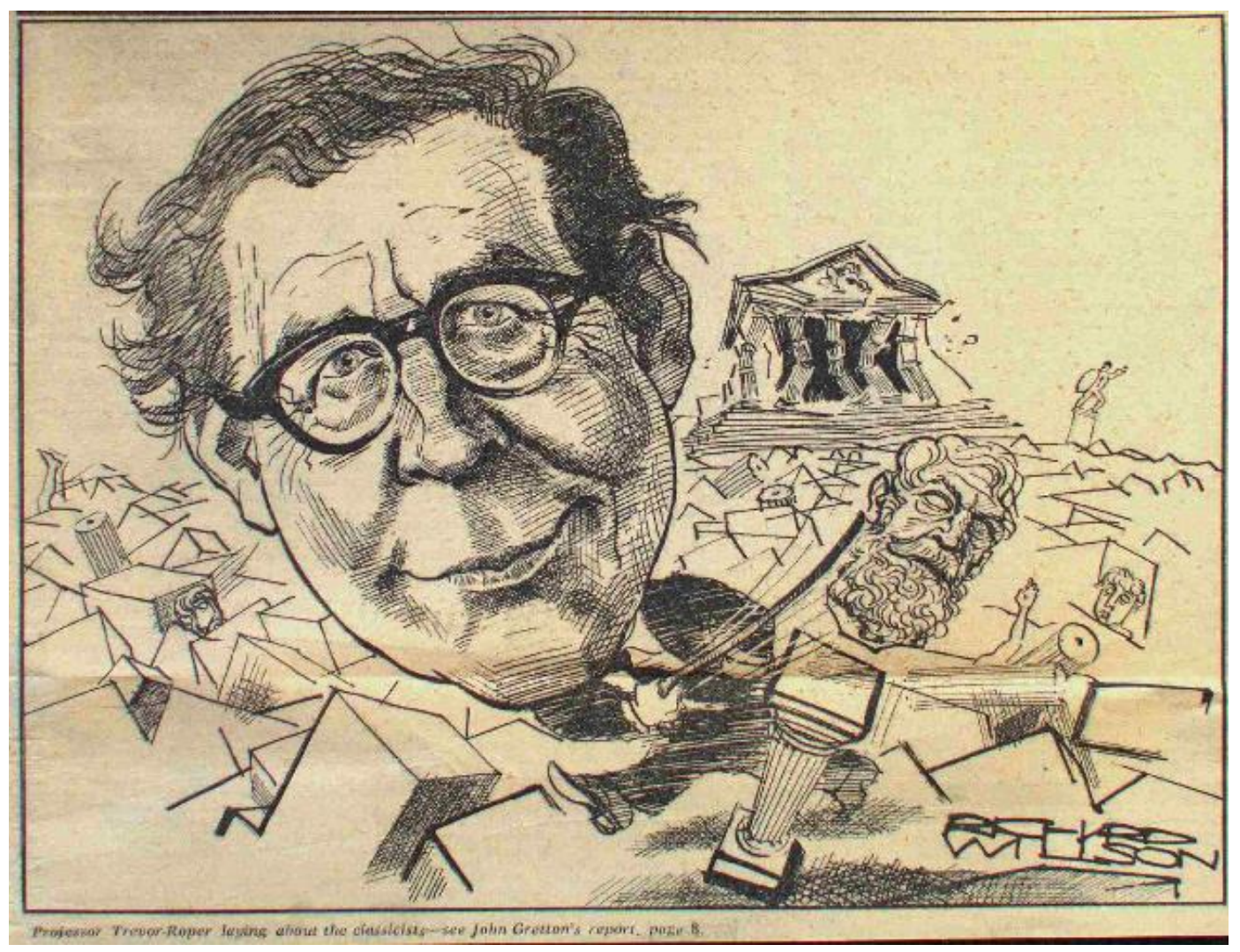

John Gretton, the TES reporter on the scene, praised the address, but misunderstood and misrepresented it. Trevor-Roper's 'brilliant' 'demolition job' of classics, Gretton reported, could hardly have been performed with 'greater wit and panache' as he 'slaughter[ed] his private demons in public - and before the very high priests of the religion, to boot'. It doubtless prompted reflections, 'over lunch, ... why he should be their president' at all. ${ }^{67}$ Gretton missed Trevor-Roper's clear statement of his 'love' and 'passion' for classical literature, which he thought might have been killed off by further formal study in his youth. ${ }^{68}$ His love of the texts that he studied had led him to explore 'every corner of ancient literature' in his spare time. ${ }^{69} \mathrm{He}$ defended the value of a classical education, praised his own teachers at school and university, and said that he 'much preferred teaching history [to undergraduates] who had read classics at school' ${ }^{70}$ Though critical of the old Oxford approach to ancient history, he praised the innovative work of Dodds and Finley. Finally, his agreement to be President of

\footnotetext{
${ }^{67}$ Gretton (1973).

68 Trevor-Roper (1974) 402.

69 Trevor-Roper (1974) 400.

${ }^{70}$ Endorsed classical education: see above. Praised teachers: Trevor-Roper (1974) 399; cf. TrevorRoper to J. Shiel, 21 January 1992 = Trevor-Roper (2014a) 381; Trevor-Roper to P. Miller, 18 March $1999=$ Trevor-Roper (2014a) 406. Preferred teaching those with a classics background: reported in Gretton (1973).
} 
the JACT was the ultimate vote of his confidence in a classical education. Scarcely, then, a demolition job.

Gretton's article provoked indignant letters to the TES from J. E. Sharwood Smith and J. W. Roberts, the Chairman of the Council of JACT, who both criticised his report of the 'Apologia' and summary of other aspects of the day's business. ${ }^{71}$ Trevor-Roper himself was prompted by Gretton's 'grotesque caricature' of his 'Apologia' to widen the audience of his lecture by printing a 'slightly abbreviated' version in The Spectator of 14 July $1973 .{ }^{72}$ In the meantime he had been corresponding with Hugh Lloyd-Jones, to whom he had sent a typescript of the 'Apologia'. ${ }^{73}$ The issues raised between the two men mattered deeply to Lloyd-Jones. He wrote a letter to The Spectator setting out his views, which were elaborated from the private correspondence, ${ }^{74}$ and republished the letter nine years later in his collection of essays, Classical Survivals. ${ }^{75}$

Lloyd-Jones enjoyed Trevor-Roper's 'Apologia', but such were his 'doubts and criticisms' that he prefaced them with the remark that 'you will not put them down to malice' ${ }^{76}$ He agreed with Trevor-Roper's concerns about the narrowness of Greek history at Oxford, but challenged him about the Roman historians: 'you say nothing about SYME [sic], a figure some twenty times more significant than Moses Finley. How about Beazley? What about Lobel?' This judgement about the relative importance of Syme and Finley, which some today will dispute, reflected the methodological disagreements of Lloyd-Jones and Finley. The two men came from very different scholarly trajectories. Educated at Westminster, Lloyd-Jones went up to Oxford in 1940, when classical studies retained the character that Trevor-Roper remembered from his youth, and earned a first in Greats in 1948. The technical

\footnotetext{
${ }^{71}$ Sharwood Smith: TES 26 June 1973; Roberts: TES 29 June 1973.

72 The audience of Didaskalos was too narrow and publication too slow to respond to Gretton. TrevorRoper described Gretton's piece as a 'grotesque caricature' in a letter of 4 June 1973 to Arthur Crook, editor of the Times Literary Supplement, where he first tried to place the 'Apologia'. John Sturrock, the Assistant editor, answered his letter in Crook's absence and referred him back to the TES (correspondence at Soc. Dacre 2/1/36).

${ }^{73}$ Lloyd-Jones had not attended the address: 'I hear enthusiastic reports of your address to the Classical Association [sic]. So this is why you were thinking about Wilamowitz...': H. Lloyd-Jones to TrevorRoper, 22 May 1973 (Soc. Dacre 2/1/36).

${ }^{74}$ Such a public statement on a subject of personal correspondence was quite normal. For example, Trevor-Roper corresponded with John Sparrow, Warden of All Souls College, Oxford, as they were publicly engaging over the Report of the President's commission on the assassination of President Kennedy. See Kidd (2011).

${ }^{75}$ Lloyd-Jones' letter was published in The Spectator of 27 July 1973, pp. 4-5. For publication in Classical Survivals, he gave it the title 'The classics in Britain today': see Lloyd-Jones (1982b) 52-5.

${ }^{76}$ H. Lloyd-Jones to Trevor-Roper, 4 June 1973 (Soc. Dacre 2/1/36).
} 
accomplishment that won him the Chancellor's Latin prose prize and the Ireland scholarship in 1947 and made him proxime accessit for the Hertford ${ }^{77}$ was displayed in editorial and textual work on Greek texts throughout his career. Although he ranged widely across fields, and like Finley, wrote with broad audiences in mind, ${ }^{78}$ his roots were very much in the philological tradition. Finley had come to the classical world quite late in his education, as a $\mathrm{PhD}$ student at Columbia, after taking a degree in psychology from Syracuse University and an MA in public law from Columbia. ${ }^{79}$ He taught ancient history at Rutgers from 1948, but was dismissed in 1952 for political reasons and thereafter made his career in England. ${ }^{80} \mathrm{He}$ pursued an historical analysis that favoured institutions and structures, which he illuminated with perspectives deriving from the social sciences. He deplored what he saw as the strangle-hold of classical philology on the study of ancient history in England. ${ }^{81}$

Lloyd-Jones respected Finley's abilities as an historian and considered him to be a deserving successor to A. H. M. Jones as Professor of Ancient History at Cambridge, ${ }^{82}$ it was probably this respect, if not a desire to avoid unnecessary polemic, that led him to omit mention of Finley in the version of his letter published in The Spectator. Lloyd-Jones did not, however, appreciate the 'special boost' that Trevor-Roper had given Finley and The world of Odysseus, a book he thought good, yet 'hardly as good' as Trevor-Roper implied and vitiated by Finley's tendency to forget that the Odyssey is a work of fiction. ${ }^{83}$ More fundamentally, however, he chafed at Finley's hostility to other approaches to the ancient world and dismissive attitude to the classical languages, in which he had never formally been schooled: ${ }^{84}$ Finley was 'the tailless fox who has had such success in persuading English classical scholars, who once got sound linguistic training, to cut off their own tails also'. The

\footnotetext{
77 Wilson (2011) 220.

${ }^{78}$ Both tendencies are in evidence, appropriately, in Lloyd-Jones' Sather lectures published in 1971 as the Justice of Zeus.

${ }^{79}$ Whittaker (1997) 460.

${ }^{80}$ See further below. Whittaker (1997) 462-4.

${ }^{81}$ Programmatic is Finley (1966). See also Finley (1982) for hostility to textual criticism in a review of works by Lloyd-Jones; Finley and Hopkins (2014) 180; Whittaker (1997) 466-7.

${ }^{82}$ H. Lloyd-Jones to Trevor-Roper, 4 June 1973 (Soc. Dacre 2/1/36).

${ }^{83}$ H. Lloyd-Jones to Trevor-Roper, 4 June 1973 (Soc. Dacre 2/1/36). For a positive view of Finley's World of Odysseus see H. Lloyd-Jones (1982a) 118-19. Finley treated the Homeric poems exclusively as 'documents about a society' (Finley and Hopkins [2014] 183), and in a later preface claimed that it was 'beside the point' that they were fiction (Finley [1978] 9).

${ }^{84}$ Cf. Finley and Hopkins (2014) 179-81.
} 
metaphor of the 'tailless fox' is one that Lloyd-Jones would subsequently elaborate in print. $^{85}$

Finley was Trevor-Roper's kind of historian. There are many signs of compatibility between the two men, beyond their rejection of the value of textual criticism. Trevor-Roper, who believed that disciplines needed to be refreshed by voices outside them, identified with Finley's origins as an outsider to classical studies, ${ }^{86}$ as he considered himself to be to historical studies. ${ }^{87} \mathrm{He}$ approved of Finley's pursuit of 'total history', which sought to combine the accounts of ancient historians with the evidence of fictional texts and material culture to shed light on historical problems. ${ }^{88} \mathrm{He}$ approved Finley's popularising streak, which echoed his own. ${ }^{89}$ But it was Finley's work on Homer that primarily generated Trevor-Roper's interest in him. The world of Odysseus was his 'favourite' 90 among recent works of classical scholarship for its use of comparative methodologies such as sociology and anthropology to illuminate the world of the Homeric epics. ${ }^{91} \mathrm{He}$ judged its approach sufficiently consistent with his own historical philosophy to include his review of the book for the New Statesman in his Historical Essays, ${ }^{92}$ which were concerned with historical problems, particularly the interplay between man and social forces or geography, and advocated a broad approach to history. ${ }^{93}$ Shortly before publishing the

\footnotetext{
${ }^{85}$ H. Lloyd-Jones to Trevor-Roper, 4 June 1973 (Soc. Dacre 2/1/36). In his second letter to TrevorRoper in this sequence he remarked that Finley 'does not know Greek well, and ... is not at ease with those who do' (11 June 1973 (Soc. Dacre 1/2/17)). In a review of Finley's The uses and abuses of history in The Spectator of 1 March 1975 (= Lloyd-Jones [1982b] 63), Lloyd-Jones extended the metaphor of the tailless fox: ' ... Greek and Roman literature played such an important part in the life and politics of its time that it is specially important to historians. Even the general student of antiquity must take adequate account of this, and no general survey which fails to do so can be recommended without reserve. The fox who had lost his tail in a trap tried to persuade all the other foxes to cut off their tails also. We know that there are very fine foxes without tails, and that is lucky, since before long the tails of all fox-cubs will be amputated in the name of social justice. But until then we shall not allow even the most eloquent of tailless foxes to persuade us to cut off our own'.

${ }^{86}$ Trevor-Roper (1974) 409. For Finley the outsider cf. Finley and Hopkins (2014) 179-80.

87 'I was trained as a classical scholar, not as a historian, of which I am glad...'? Trevor-Roper to P. Miller, 18 March 1999 (= Trevor-Roper (2014a) 406). On Trevor-Roper's 'unorthodox intellectual formation' see Ghosh (2011) 485. Although he regarded himself as an historian of the sixteenth and seventeenth centuries (cf. Trevor-Roper (2006) 10,116), Trevor-Roper ranged widely in the nineteenth and twentieth centuries (to use only chronological parameters); cf. Ghosh (2011) 493.

${ }^{88}$ Cf. Whittaker (1997) 470-71.

${ }^{89}$ Cf. Hornblower in Finley (2002) xvi (discussing The world of Oysseus); Finley and Hopkins (2014) 185; Naiden and Talbert (2014) 172-3.

90 'Apologia' typescript p. 20 (Soc. Dacre 2/1/36) = Trevor-Roper (1974) 409. In the published version Trevor-Roper opted for the more neutral 'more recently there is...'.

${ }^{91}$ See Trevor-Roper to I. Berlin, 18 February $1955=$ Trevor-Roper (2014a) 52. For Finley's method cf. Finley (1978) 9; Hornblower in Finley (2002) xvi-xx. Finley himself judged his innovative approach to be the most important achievement of the book: Finley and Hopkins (2014) 183-4.

92 Trevor-Roper $(1956)=(1957 \mathrm{a})$ 6-11.

${ }^{93}$ Trevor-Roper (1957a) vi. For the Essays see above n. 8; Ghosh (2011) 489-92.
} 
review, Trevor-Roper wrote to Bernard Berenson, the American art critic living outside Florence, that he thought the book 'wonderfully good; fresh and clear and illuminating: I have never read anything so fresh and exciting on the Homeric age, and so completely free from pedantry'. Such was his excitement at reading the book that in 1955 he had tried to recruit Finley to Christ Church, only to be pre-empted and outbid by an offer from Cambridge procured by Trevor-Roper's old tutor, D. L. Page, the Regius Professor of Greek. ${ }^{94}$ Finley was then a guest lecturer in Britain after his dismissal from Rutgers in 1952 on the ground that he refused to respond to allegations that he had been a member of the Communist Party when called on to do so before a Senate sub-committee. ${ }^{95}$ Although Trevor-Roper, the scourge of Marxist historiography, ${ }^{96}$ would not have supported Finley as a paid-up member of the Communist party, he was prepared to accept him merely as a 'fellow traveller' ${ }^{97} \mathrm{He}$ took a more moderate line on Finley's politics in the mid-1950s, when they mattered more, than Lloyd-Jones did twenty years later, when they mattered less: Finley was a 'Communist interloper' and a 'dedicated Marxist of a rather grim and humourless kind' ${ }^{98}$ In reply Trevor-Roper was still not persuaded: 'As for Moses Finley... (sic) well, he may be a "communist interloper" and a "tailless fox", but I must admit that I found The World of Odysseus exciting nevertheless!'.99

Lloyd-Jones agreed with Trevor-Roper's portrait of Housman's narrow interest in textual criticism. ${ }^{100}$ Earlier in 1973 he had written more fully of Housman's

\footnotetext{
${ }^{94}$ Trevor-Roper to Berenson, 10 June 1956 = Trevor-Roper (2006) 198-99. Robert Blake, who was against Finley, wrote to Trevor-Roper that Page was confident that Cambridge would offer Finley a university lectureship but were waiting to see what move Christ Church made: R.Blake to TrevorRoper, 11 April 1955 (Soc. Dacre 1/2/3). Finley claimed not to have known of the Cambridge offer until he had been appointed: Finley and Hopkins (2014) 181.

${ }_{95}$ Whittaker (1997) 464; Hornblower in Finley (2002) xii.

${ }^{96}$ Having gone through a phase of sympathising with its materialist explanation: Worden (2007) 257; Ghosh (2011) 492.

${ }^{97}$ While urging Finley's case at Oxford he wrote to Isaiah Berlin for information on this very question: see Trevor-Roper to I. Berlin, 18 February $1955=$ Trevor-Roper (2014a) 51-2. For an apparent attempt from the U.S.A. to thwart Finley's fortunes in Oxford at this time see Tompkins (2013) 30.

${ }^{98} \mathrm{H}$. Lloyd-Jones to Trevor-Roper, 4 June 1973 (Soc. Dacre 2/1/36).

${ }^{99}$ Trevor-Roper to H. Lloyd-Jones, 7 June 1973 (Soc. Dacre 2/1/36). Comparable to Trevor-Roper's excitement about The world of Odysseus was his discovery of J. Carcopino's Les Secrets de la Correspondance de Cicéron (1947), which, he told Berenson, 'I have been unable to stop reading' out of curiosity about Cicero and the publication of his correspondence (Trevor-Roper to Berenson, 16 April $1948=$ Trevor-Roper (2006) 14-15), and his fascination at the story of Michael Ventris in J. Chadwick's The decipherment of linear B (1958), which he also described to Berenson: 'I picked up the book full of doubts - it looks so formidable - and then couldn't put it down. I have now persuaded the Sunday Times to let me puff it in its astonished pages' ('astonished' is Gibbonesque): Trevor-Roper to Berenson, 13 August 1958 = Trevor-Roper (2006) 255-6. Trevor-Roper's review appeared in the Sunday Times of 7 September 1958.

${ }^{100}$ See also the appendix below.
} 
continuation of the eighteenth-century tradition of textual criticism, embodied locally in the work of Richard Porson, in preference to pursuing nineteenth-century developments in classical scholarship. ${ }^{101}$ Agreement with Trevor-Roper about Housman did not of course imply that Lloyd-Jones rejected textual criticism as a valuable scholarly exercise. He told him - rightly - that 'we still have to have some people capable of judging a reading, in order to have proper texts of the main authors, and in order to make sure that their words are rightly understood'. He offered to show Trevor-Roper the emendations made on new texts being discovered on papyri and ask him if he thought them to be 'pure fantasy' ${ }^{102}$ Similarly, Lloyd-Jones disliked the impression that Trevor-Roper had given that 'all emendation is fraud'. Trevor-Roper had claimed that the frequency of errors of omission was 'the cause of many corruptions in ancient manuscripts. With that assumption', he continued, 'all the "palmary emendations" from Scaliger to Housman disappear, like piffle before the wind'. ${ }^{103}$ Lloyd-Jones regarded this deduction as 'ignorant and superficial' and hoped that Trevor-Roper would not print it. ${ }^{104}$

If Lloyd-Jones agreed with Trevor-Roper about the narrowness of Housman's interest in textual criticism, he would not accept the same judgement about Wilamowitz. He pointed out the great flourishing of classical studies in Germany in the first half of the nineteenth century under the aegis of a totalising approach to the study of ancient civilisations (Altertumswissenschaft). He explained that the specialisation of the latter part of the century had arisen not, as Trevor-Roper claimed, from an attempt to 'mask the remoteness of [classical studies] from contemporary reality', but from an interest in studying antiquity a whole. The 'danger' of this approach, as Lloyd-Jones saw it, lay in the attempt to study every element of the civilisation in detail. ${ }^{105}$ Wilamowitz, for Trevor-Roper the villain of the piece, was for

\footnotetext{
${ }^{101}$ Lloyd-Jones (1982a) 184 (a review of Diggle and Goodyear (1973)). In his letter to Trevor-Roper, however, Lloyd-Jones undid Trevor-Roper's coupling of Bentley and Porson as representative of the eighteenth-century tradition with the remark that Bentley's scholarship, especially his Dissertation on the epistles of Phalaris, had wider methodological ramifications for the development of classical scholarship (H. Lloyd-Jones to Trevor-Roper, 4 June 1973 (Soc. Dacre 2/1/36)).

${ }^{102}$ H. Lloyd-Jones to Trevor-Roper, 4 June 1973 (Soc. Dacre 2/1/36). In the 'Apologia' Trevor-Roper had said, 'Whenever I see a particularly ingenious emendation of a particularly difficult text, I assume that it is pure fantasy' ('Apologia' typescript p. 19 (Soc. Dacre 2/1/36)).

103 'Apologia' typescript pp. 19-20 (Soc. Dacre 2/1/36). For the expression 'piffle before the wind' cf. Daisy Ashford, The young visiters (London, 1919) chapter 5: 'Oh I see said the earl but my own idear is that these things are as piffle before the wind'.

${ }^{104}$ H. Lloyd-Jones to Trevor-Roper, 4 June 1973 (Soc. Dacre 2/1/36).

${ }^{105}$ H. Lloyd-Jones to Trevor-Roper, 4 June 1973 (Soc. Dacre 2/1/36). In his letter to The Spectator (27 July 1973, p.4 = Lloyd-Jones (1982b) 52) Lloyd-Jones states that the historicism of the period
} 
Lloyd-Jones the scholar who had revitalised the broad approach when, around 1870, specialisation was at its worst. It was 'quite absurd to accuse him of a purely literary and philological approach to the classics'; he was 'not a pedant, and he never lost sight of the idea that antiquity must be studied as a whole'. Lloyd-Jones considered Trevor-Roper's characterisation of Wilamowitz to be so wide of the mark that he accused him of not having read Wilamowitz properly. ${ }^{106}$

Lloyd-Jones similarly resuscitated Fraenkel. In his letter to Trevor-Roper he pointed out that Fraenkel, though initially unpopular in Oxford, was eventually welcomed by the classical establishment, and questioned whether Fraenkel's personal faults reduced the worth of his scholarship (Trevor-Roper had not said as much explicitly, but his concentration on Fraenkel's personal qualities seemed designed to colour opinion of his work by providing it with an objectionable personal context). In the letter he sent to The Spectator he defended Fraenkel's character without whitewashing it and placed him firmly in the tradition of Wilamowitz as devoted to the study of classics in all its branches. ${ }^{107}$ He probably devoted more space to Fraenkel in his public response because Trevor-Roper left his portrait of Fraenkel largely unaltered in the published version of his 'Apologia', and memories of Fraenkel were still fresh and reverent.

In response to Lloyd-Jones' letter, Trevor-Roper altered his text to allow for the flourishing of scholarship and culture in Germany in the first half of the nineteenth century, ${ }^{108}$ toned down his judgement on textual criticism, ${ }^{109}$ and added a

\footnotetext{
destroyed the notion that ancient Greece and Rome provided models of imitation because those societies and modern Germany resembled each other. The ideology of Altertumswissenschaft demanded the study of a whole civilisation, but those of Greece and Rome were only two among many, and worthy of study - as Trevor-Roper would have agreed - because of their 'special historical relation to modern Europe' and the 'intrinsic interest' of their history and literature.

${ }^{106}$ H. Lloyd-Jones to Trevor-Roper 4 June 1973 (Soc. Dacre 2/1/36).

107 The Spectator 27 July 1973, p. 4 = Lloyd-Jones (1982b) 53-54. Lloyd-Jones published an obituary of Fraenkel in Gnomon 43 (1971) 634-40 = (1982a) 251-60. As he remarks in his letter to TrevorRoper, he devotes some space in the obituary to illustrating Fraenkel's difficult personality (1982a: $254,255,257)$ and mentions his wide learning (258). Trevor-Roper replied that he did not think there was a 'great gulf' between them about Fraenkel. For Fraenkel's range see also Nisbet (2007) 221; West (2007) 203.

${ }^{108}$ I note the changes in italics: 'In Britain, the classics could at least be recommended as the literature of liberty, of equality among free [men>] citizens. In [Germany after 1870 they>] the first half of the 19th century that was no doubt possible in Germany too. That was the Blütezeit of German culture and scholarship. But after 1850, humanist teaching in Germany had to be adapted to a society...': 'Apologia' typescript p. 5 (Soc. Dacre 2/1/36) = Trevor-Roper (1974) 397.

109 Trevor-Roper struck out the sentence in which he damned ingenious emendations as 'pure fantasy' and toned down his judgement on textual criticism generally and on errors of omission in particular. Textual criticism: 'Now (I am afraid) I view the whole exercise with almost total scepticism' ('Apologia' typescript (Soc. Dacre 2/1/36) p. 19) > 'Now (I am afraid) I view these ingenious
} 
minor concession about Fraenkel (see below). But his portrait of Wilamowitz remained essentially the same, and in fact he heightened its rhetorical colour. ${ }^{110}$ Trevor-Roper reassured Lloyd-Jones that he had read some of Wilamowitz's works, was finally put off by his Sappho und Simonides (1913), and admitted that he was mostly irritated by the 'cult' of Wilamowitz. ${ }^{111}$ His main line of defence, however, lay in the subjectivity of his impressions: the aim of his 'Apologia' had not been to supply an objective account of the state of classical scholarship, but an essay in intellectual autobiography. He claimed that he was not judging Wilamowitz's work or attempting to represent its true content, but seeking to convey 'juvenile' impressions which, he reminds Lloyd-Jones, he had stressed were 'no doubt erroneous' and 'irrational': 'the figures of Wilamowitz and Housman were to me stereotypes, not realities'. ${ }^{112}$ His revisions emphasised these points still further: 'We all dramatise our own past. No doubt my own juvenile judgment was very faulty. No doubt I read the wrong works of Wilamowitz. Everyone agrees that Dr Fraenkel mellowed greatly in later years. But still...'.113

Trevor-Roper's claim in his 'Apologia' that he had not read a word of Greek for several years after transferring his studies to history was a simplification. ${ }^{114}$ In fact he had continued to study classics for two terms after 1934. His tutor D. L. Page

reconstructions with considerable scepticism' (Trevor-Roper (1974) 409). Errors of omission: 'Apologia' typescript pp. 19-20, quoted above p. 19 (Soc. Dacre 2/1/36) > 'I now assume that such omissions are the cause of many corruptions in ancient manuscripts, and ingenious conjecture is effort wasted' (Trevor-Roper (1974) 409). Trevor-Roper's retreat was principally in rhetoric, not in substance.

${ }^{110}$ Quoted above p. 9. Trevor-Roper originally introduced Wilamowitz (and Housman) as follows: 'out of the haze there emerge two hostile, glowering faces: first, the grim, Prussian visage of Ulrich v. Wilamowitz-Moellendorf; then, behind him, longo intervallo, the sour, crabbed figure of A. E. Housman' ('Apologia' typescript p. 9 (Soc. Dacre 2/1/36)).

111 On Sappho und Simonides, Trevor-Roper remarked: 'I remember the otiose polemic against Pierre Louÿs (!), the presentation of Sappho as a respectable Teutonic nymph of the Vistula, which was helped (if I remember aright) by a quiet readjustment of her vocabulary: where Sappho wrote $\varphi ı \lambda o ́ \tau \eta c$, Wilamowitz wrote $\varphi \imath \lambda i ́ \alpha$. But I suppose what really irritated me against Wilamowitz was the cult, which reminds me, in retrospect, of the cult of Stefan George. My emotion was like that of the Athenian peasant who was sick of the humbug about Aristides. I understand that this cult still goes on, with incense, candles, and the full apparatus of idolatry, at Pisa. Is this true?' Trevor-Roper to H. Lloyd-Jones, 7 June 1973 (Soc. Dacre 2/1/36).

112 Trevor-Roper to H. Lloyd-Jones, 7 June 1973 (Soc. Dacre 2/1/36).

113 'Apologia' typescript p. 16 (Soc. Dacre 2/1/36) (I italicise the additions) = Trevor-Roper (1974) 406 (see also 399, 400).

114 Trevor-Roper (1974) 399. 
reported 'brilliant work done in odd moments stolen from his history tutors' ${ }^{115}$ that was reflected in his winning the Ireland scholarship and improving on his two honourable mentions in the Gaisford prize for Greek verse composition by being proxime accessit in his third attempt. ${ }^{116}$ His first publication, produced at the end of his undergraduate career, was an essay entitled 'Homer unmasked!', in which his love of classical literature is manifest. ${ }^{117}$ But it also parodies traditional classical scholarship. This 'scholarly little opusculum' surveyed Homer's knowledge of horses - 'sometimes a trifle elementary' - and the racetrack - where he becomes a 'specialist' - to solve the 'Homeric question': Homer was a bookmaker, at home in the military race-meeting of Iliad 23, learned in stables, horse-breeds, and the principal race-meetings of Greece, and prepared to read into his story the bookie's philosophy, 'that the Gods, in their dealings with men, always take two to one in the field' (citing Il. 24.527ff.). ${ }^{118}$ Homer had the 'wide view of the bookmaker, who saw life steadily and saw it from a collapsible stool on the course', not the outlook of 'the snobbish racing journalist, Pindar, who always wore spats and liked to be seen chatting to tyrants in the Club Enclosure'. ${ }^{119}$ This essay happily brought together several of Trevor-Roper's passions: reading Homer, riding in points-to-point, and hunting. ${ }^{120}$ Frivolity and irreverence, however, vie for attention with the subject matter:

\footnotetext{
'Who is Homer?' asked jesting Wolf, and did not stay for an answer. And ever since, poor Homer has been fighting a defensive action, desperately keeping Wolf from the door, afraid to disclose himself. But yesterday a more spirited policy prevailed; there was a hoot and toot and tally-ho, and he sallied from my bookshelf, quoting himself, and finally closed the Homeric question by proving that Wolf is not Wolf at all, but only Sheep in Wolf's clothing, and that Homer is...(sic)

'Who is Homer?' asks the panting reader (if anyone is still reading this scholarly little opusculum). Of course, I am now in a position to announce ex cathedra who Homer is,
}

\footnotetext{
115 Sisman (2010) 36.

116 Ireland: Oxford University Gazette 65 (1934-1935) 292; Gaisford: ibid, 679.

117 Trevor-Roper (1936).

118 Trevor-Roper (1936) 515-16.

119 Trevor-Roper (1936) 517.

120 Trevor-Roper was bred to an interest in horse-racing by his father (Sisman (2010) 5-6). He mentions riding in point-to-points in letters to his brother Pat in this period (16 February 1935, 25 February 1935 (Soc. Dacre 1/3/17)), and his love of hunting is attested throughout his wartime notebooks (e.g. TrevorRoper (2015) 176-7, 181-87). This passion presumably combined with the recent presentation of some of Somervile's correspondence to the British Museum to inspire his essay 'William Somervile: the poet of the chase' (see Trevor-Roper (1939)), on which cf. Trevor-Roper to L. Pearsall Smith, 18 September $1943=$ Trevor-Roper $(2014 \mathrm{a}) 5$.
} 
and justify the answer by revelation: but I will condescend to proof: so let there be no cavilling by fractious professors. ${ }^{121}$

Trevor-Roper claims to know Homer's identity through revelation but agrees to proceed according to the scholarly rules of engagement by supplying proofs for his unitarian solution in the form of the relevant evidence from the Iliad. ${ }^{122}$ The couching of conventional argumentation in a jocular tone supplies a clever parody of a tradition in classical scholarship of trying to solve the 'Homeric question'. Irreverence and liminal posturing are qualities that will recur in Trevor-Roper's life. Here they combine with his eccentric solution to point to Samuel Butler as a source of inspiration. In The Authoress of the Odyssey (1897) Butler argued that the Odyssey was composed by a Sicilian woman from Trapani who wrote herself into the text as Nausicaa, princess of Scheria. ${ }^{123}$ Butler combined a lighter tone that was occasionally jocular with serious argumentation. He offered his work as a contribution to scholarship, and apparently never agreed that it was the parody that it was taken to be, when it was not ignored altogether. ${ }^{124}$ Rejection of his work would have confirmed Butler's low judgment of classical scholarship as pedantry:

\footnotetext{
There was... a band of scholars some few hundred years before the birth of Christ, who refused to see the Iliad and Odyssey as by the same author but they were snubbed and snuffed out, and for more than two thousand years were considered to have been finally refuted. Can there be any more scathing satire upon the value of literary criticism? It would seem as though Minerva had shed the same thick darkness over both the poems as she shed over Ulysses, so that they might go in and out among the dons of Oxford and Cambridge from generation to generation, and none should see them...Students of the Odyssey for the most part are so engrossed with the force of the zeugma, and of the enclitic particle $\gamma \varepsilon$; they take so much more interest in the digamma and in the Aeolic dialect, than they do in the living spirit that sits behind all these things... 125
}

\footnotetext{
121 Trevor-Roper (1936) 514.

${ }^{122}$ Cf. Trevor-Roper to H. Lloyd-Jones, 7 June 1973 (Soc. Dacre 2/1/36): 'I am glad that you reject the theory that Iliad ix and xxiii are "interpolations". They seem to me artistically (and especially by Greek artistic canons) integral and essential points of the poem'. See also Trevor-Roper to Lloyd-Jones, 25 September 1981 (Soc. Dacre 1/3/30). For background to the Homeric question see e.g. Lloyd-Jones (1981).

${ }^{123}$ Apparently the writer's interest in and knowledge of women gave her sex away: Butler (2003) 7-8, 105-106. Trapani: 162, 200. Nausicaa: 206-07.

${ }^{124} \mathrm{Cf}$. Whitmarsh (2002) 75-78.

${ }^{125}$ Butler (1913) 97-98 (= 'The Humour of Homer', 'a lecture delivered at the Working Men's College, Great Ormond Street, 30th January, 1892'); cf. also Whitmarsh (2002) 72-3.
} 
'Homer unmasked' also looked forward. Trevor-Roper's historical interest in Homer's poetry placed him on the same intellectual trajectory as Finley, who, twenty years later, would read Homer for historical purposes in The World of Odysseus.

'Homer unmasked!' was written at the height of Trevor-Roper's interest in Butler. Butler stimulated his creativity; but he also exerted influence in the period when Trevor-Roper abandoned classics for history. In November 1934 he purchased the Further extracts from Butler's notebooks that were published in that year and marked two passages hostile to classical scholarship: ${ }^{126}$

\section{THE GREATEST HAPPINESS OF THE GREATEST NUMBER}

This would require the immediate suppression of all the Greek and Latin classics. There can be little doubt that these, unless in good translations (Greek and Latin being taught as absurdly as they are), cause far more pain than pleasure.

\section{OXFORD AND CAMBRIDGE}

...I have sampled their classics, and have satisfied myself that there is not a leading light among them who either knows or wants to know anything of the Odyssey beyond its grammar. $^{127}$

Writing in 1940-41 Trevor-Roper supplied the context and acknowledged the influence. He had discovered Butler while a freshman undergraduate, in an anthology of English prose and verse, and was seduced by his style and wit. He bought more of his works and unconsciously absorbed his 'solvent ideas':

I became an enthusiastic disciple and evangelist of Samuel Butler, and found co-religionists to keep the flame of my faith a-burning... I turned my back on the prim, traditional paths of classical learning, along which I was so profitably treading... ${ }^{128}$

\footnotetext{
126 Trevor-Roper's copy of Butler (1934), which is in my possession, is inscribed by him 'Nov. 1934'. The only other work by Butler listed in booksellers' catalogues of Trevor-Roper's personal library is Butleriana. Ed. A. T. Bartholomew (London, 1932), in G. Heywood Hill's catalogue of Spring 2004, From the library of Hugh Trevor-Roper, Lord Dacre. Classical books belonging to Trevor-Roper and offered for sale after his death can be found both in The working library of Lord Dacre from Toby English and in The antiquarian books from the library of Hugh Trevor-Roper, Lord Dacre, being catalogue 312 from E. M. Lawson \& Co. On Trevor-Roper's library see J. Catto's essay in the Heywood Hill catalogue; Saumarez Smith (2014).

127 Butler (1934) 27, 323.

128 Trevor-Roper (2015) 31-2.
} 
Around the same time Trevor-Roper wrote that Butler had caused this 'first revolution' of his mind in 1934 (the year he switched to history) and that 'the effects lasted till 1935-6', the period in which 'Homer unmasked!' was published, 'before they were completely assimilated'. ${ }^{129}$ Why did he omit Butler from his 'Apologia'? Butler's uncomfortable relationship with the classical establishment of Victorian England and eccentric scholarship hardly lent authority to Trevor-Roper's view of classical scholarship. But of course he did not need to call on Butler's support. He had personal experience to elaborate on, and he preferred to conjure up established figures in the discipline that alienated him. Butler offered confirmation of Trevor-Roper's low regard for classical scholarship; if his influence went further - if he was a prompt rather than a prop - he was one factor among many influencing Trevor-Roper at the time.

Trevor-Roper was inspired by Butler's Note-books to keep his own during the war. ${ }^{130}$ In their reflections on life, people, and books, they bear witness to his determination to sustain his intellectual life during service in military intelligence that could be tedious and frustrating. ${ }^{131}$ In particular they reveal the depth of his love of classical literature and appreciation of classical literary style. The title he gave them advertises this intellectual interest at the start of the enterprise: $\pi \tau \varepsilon \rho o ́ \varepsilon v \tau \alpha$, 'winged (words, thoughts)', from Homer's ह̌ $\pi \varepsilon \alpha \pi \tau \varepsilon \rho o ́ \varepsilon v \tau \alpha .{ }^{132}$ In an entry of 1942 that is vaguely reminiscent of Macaulay, Trevor-Roper records that since the start of the war he had reread 'all Homer, Pindar, Thucydides, Lucretius, [and] Horace.' 133 They are only some of the ancient writers who populate the notebooks up to Augustine, Procopius, and Pseudo-Dionysius the Areopagite in the sixth century.

The notebooks vividly illustrate the importance of the country to TrevorRoper in this period. 'Woods and streams and hills, how I do love them!', he wrote in December 1942, 'It is among them that I feel capable of some of the intensest

\footnotetext{
129 Trevor-Roper (2015) 37.

${ }^{130}$ Davenport-Hines in Trevor-Roper (2015) 1-2, 11.

${ }^{131}$ Davenport-Hines in Trevor-Roper (2015) 11.

132 See the four wartime notebooks at Soc. Dacre 13/29/1-4. The Homeric title does not occur in Trevor-Roper (2015).

${ }^{133}$ This classical reading was in addition to 'much of Dante, Shakespeare, Milton and Tennyson': see Trevor-Roper (2015) 71. In his 'Apologia' Trevor-Roper (1974: 396) quoted, in 'mingled astonishment and almost disgust', the intimidating list of classical authors whom Macaulay read (some twice through) in India in thirteen months. He presumably quoted Macaulay from Trevelyan (1876) 1.443-4 = Pinney (1974-81) 3.159-60. The full letter, written to T. F. Ellis from Calcutta on 30 December 1835, reveals that Macaulay was reading Greek and Latin for three or four hours before breakfast each day.
} 
pleasure I know, and their images in literature and art evoke in me the image of that same felicity'. 134 'Image' is a key concept: Trevor-Roper claimed not to be able to understand anything which he could not present to himself in pictorial form, and use of imagery was an essential ingredient of his style. ${ }^{135}$ Those country scenes he loved to paint with words were figured and elevated through classical authors. Horace, for example, complemented an idyllic morning in the country before a hunt at Ham Green:

it was a mild morning, and I walked abroad, and the fields were still dewy and the bare woods black, dead black, against the white morning sky; and I sat on a gate, my senses dwelling on the scene, and read in my pocket Horace of the pastoral world of Calabria, and Liris, now Garigliano, the silent stream, and Galaesus, and the creaking oakwoods of Garganus. ${ }^{136}$

Horace was also a regular companion in pastoral solitude. In April 1943 Trevor-Roper fished on the river Twill:

... I could taste the ecstasy of the place; for the water was clear, the weather fine, the trees, not yet in full leaf, were all in flower, sallow, weeping willow, and slender birch-trees, and the birds sang in them; and through that bright, translucent air the Cheviots loomed across the intervening landskip of cornfields and meadowlands. I thought of Horace at Tivoli and in Calabria.... ${ }^{137}$

Horace was with Trevor-Roper, too, when he travelled alone to Iceland in September 1946 ('my only human companions were in books' ${ }^{138}$ ), and he quoted Odes 1.3.9-14 as expressive of 'five days of tempestuous buffeting in the North Atlantic sea'. ${ }^{139}$ But it is perhaps the picturesque entry on Coldingham in Berwickshire which best captures the contribution of the classical to Trevor-Roper's appreciation of pastoral solitude:

\footnotetext{
134 Trevor-Roper (2015) 120; cf. 208.

135 Trevor-Roper (2015) 113, 122; cf. (2014a) 137: 'I make it a rule never to use a metaphor unless, with my mind's eye, I see the action or object from which I draw the image' (Trevor-Roper to A. Macfarlane, 22 January 1967).

136 Trevor-Roper (2015) 121.

137 Trevor-Roper (2015) 155.

138 Trevor-Roper (2015) 284.

139 Trevor-Roper (2015) 282.
} 
How happy some places make me...now Coldingham, where I stayed with John and Nim Church in that delightful house of theirs which discovers itself, like the gingerbread house in the story, quite suddenly, at the end of a long ride in a wood. There I would take the dogs out, with or without a gun, and walk out of the wood and over the moor; or I would go to the top of the wood, and from the eminence there would overlook a vast distance bounded by the Cheviots on one hand and by the Lammermuirs on the other, and in front by the sea. In that clear air, all the autumn colours stood out, the colours of golden corn standing in the fields, or stubble-fields dotted with cornshocks, or green pasture, or moor in heather-flower; and there was a pastoral loneliness, that most exquisite loneliness, that Lucretius so happily describes [at 5.1387].

Per loca pastorum deserta atque otia dia

that is emphasised rather than broken by the noise of rooks and pigeons and curlews... ${ }^{140}$

The countryside and its fauna produced some of Trevor-Roper's most beautiful writing and would endure in his stylistic repertoire as a source of metaphor and analogy.

Trevor-Roper's intensely visual writing about the natural world locates one source of the literary appeal of the ancients, from Homer to Augustine. ${ }^{141} \mathrm{He}$ was interested in classical language and literary forms, too, as part of his quest to cultivate his own literary style under the inspiration of his mentor Logan Pearsall Smith. ${ }^{142}$ His favourite Latin prose authors, he wrote in March 1944, were Apuleius and Augustine, those 'baroque' authors, who 'recreated their Latin language in its long sterility':

The majestic Cicero, the virtuous Livy, the sententious Seneca, the judicious Quintilian, the elegant Pliny, I have read them all, and never again, I fear, will I read a word of any of those august and meritorious dead. I can dispense even with Columella. Nor are Paterculus and Macrobius often to be found at my bedside. And how rarely, out hunting, do I think of Fronto! For me, Latin prose literature consists of two works only: the Metamorphoses of

\footnotetext{
${ }^{140}$ Trevor-Roper (2015) 100-01; cf. 75 for the same quotation under the rubric 'magic lines'. TrevorRoper quoted the line from Lucretius when mentioning 'those pastoral solitudes which I so pursue' in a letter to Berenson, 16 April 1948 (= Trevor-Roper (2006) 14), and in a notebook entitled ' 1963 ' in describing a visit to Holker Hall (Soc. Dacre 13/29).

${ }^{141}$ E.g. ' ....out hunting...I think of Homer's great images of beasts in the forest' (Trevor-Roper (2015) 105); 'I have noticed how attractive the unattractive, austere, baroque character of St Augustine is [in his imagery], for he evidently loved the country and wild creatures too, and the subleties of light and colour' (115).

${ }^{142}$ For Smith see Trevor-Roper (2015) 280-81; Worden (2007) 254-55. Among English-language models, Trevor-Roper was inspired by Gibbon, not least in his ornamentation, but in the smoothness of his prose he most resembles Macaulay. Both of course were classical stylists.
} 
Apuleius, and the Confessions of St Augustine. Those two old Africans I could read every year, as the good bishop Huet read Theocritus annually, in the month of May. ${ }^{143}$

Apuleius was particularly stimulating. After Smith had revealed to Trevor-Roper that adverbs were the secret of style, he discovered that Apuleius had made the same discovery in the Latin tongue. When he wrote a Bodleian Oration in 1946, he took Apuleius for his model and 'contrived to include no less than 73 adverbs'. ${ }^{144}$ Some of them occur only in Apuleius. ${ }^{145}$ Influenced by the innovation and linguistic richness of such authors, Trevor-Roper advocated a more general use in English of Latin abstract neuter nouns ending in -um in preference to adjectives ending in -ousness, ${ }^{146}$ and embellished his own classical style with baroque Latinate vocabulary. ${ }^{147}$ In a wartime notebook, for example, he describes the prose style of John Henry Newman as 'majestic, but deliquescent, - an old eighteenth-century mansion in Ireland, derelict and forlorn among the silent superstitious bogs and hills... ${ }^{148}$ Recherché 'deliquescent' complemented the period, pastoral metaphor which it introduces, and it points the contrast with Gibbon's style in the same passage: 'firm, spacious, and technically faultless; like a stately eighteenth-century house, the mansion of an English duke.... 149

During the war Trevor-Roper found Virgil lacking in 'intesity of lyrical feeling' and 'vividness of imagination', and it was only in later life that he elaborated

\footnotetext{
${ }^{143}$ Baroque: Trevor-Roper (2015) 62, 115, 119. Sterility: 191. Favourites: see notebook entitled ' $\pi \tau \varepsilon \rho o ́ \varepsilon v \tau \alpha / 1944-'$, p. 246 (Soc. Dacre 13/29/3; the passage is not in Trevor-Roper (2015)). 144 Trevor-Roper (2015) 289, where some are listed. The Bodleian oration is preserved at Soc. Dacre 2/1/37. An ink inscription in Trevor-Roper's hand calls it 'The "Apuleian oration"'.

${ }^{145}$ E.g. aggeratim only at Apul. Met. 4.8 (TLL I.2 1310.19-21); contraversim only at Apul. Apol. 15 (TLL IV 788.6-8); fistulatim only at Apul. Met. 4.3 (TLL VI 830.79-81). Trevor-Roper clearly took pullulatim from its sole attestations in Apuleius (Met. 2.16.3, 5.20.4); it is normally regarded as a corruption of paululatim (TLL X.1 827.2-7; X.2 2584.9-11).

146 Trevor-Roper (2015) 61; Trevor-Roper to L. Pearsall Smith, 21 October 1944 (Soc. Dacre 1/3/18). In the wartime notebook he urged use of 'meticulum, obsequium, fastidium, supercilium, bogum, impecunium'; the later letter added ridiculum.

${ }_{147}$ The style of Apuleius exhibits a mixture of classical and baroque: see Kenney (1990) 30-1. TrevorRoper meditated on the appeal of the classical and the baroque in the entry 'Classical and Romantic' (June 1945): 'I have pretended, and still pretend, to a classical style and classical values; to a love of the 18th century in all its attitudes and expressions, - its firm, complete and polished world of knowledge, and thought, and prose, and poetry, and art, and architecture. But the pretence has never really been successful. Why not drop it, and admit it was a pose? That the baroque and the romantic are what I really love?...'.

148 Trevor-Roper (2015) 189; cf. 91 (deliquescence).

${ }^{149}$ Note, in both descriptions, Trevor-Roper's characterisation of literary style in visual and pastoral terms. For other Latinate vocabulary in the wartime notebooks see e.g. 'servitor' (74); 'percolating up steep, winding lanes, and over the moors' (215).
} 
publicly on the 'stylistic miracles' that he admitted in his poetry. ${ }^{150}$ But Virgil held an honoured place in Trevor-Roper's repeated engagement with literary form in the wartime notebooks. It was a sign of greatness, he wrote, 'so to have perfected a form or technique that posterity can do no more with it'. ${ }^{151}$ When Augustans such as Virgil and Horace took up and perfected in Latin the metres that the Greeks had mastered, he wrote in 1945, 'their successors just went on churning them out - Statius, Lucan, Valerius Flaccus, Silius Italicus, Ausonius, Claudian, successive generations of dreary hacks'. ${ }^{152}$ Trevor-Roper ruminated in the same context on new prose forms. ${ }^{153}$ Between notebooks that 'catalogue the unhewn raw material' of a Leonardo or a Coleridge and the masterpiece of the Last Supper or The Rime of the Ancient Mariner lay 'a great act, an act requiring labour and patience, the act of a demiurge: the imposition of artistic form'. ${ }^{154}$ He believed Augustine's Confessions to be a masterpiece, 'because, by toil and sweat, through lonely vigils and intellectual agony, he imposed a unity on his fierce, recalcitrant, tumultuary imaginings, amd wrought a new vessel capable of holding them'. ${ }^{155}$ When Smith tried to argue that 'low-life, the life of the people', not scholars and intellectuals, will create a new form, TrevorRoper took refuge in the example of Augustine:

...he always comes to the rescue...the image of that intolerant old African, with his hot-house rhetoric, his chromatic imagination, his steaming repressions, seemed to rise before me out of a lurid, simmering volcano, and puff away these facile generalities [of Smith's]. ${ }^{156}$

Trevor-Roper was here concerned with form in literature, but his classical interests form part of the background to his struggle with form in his own historical projects. One book that he was already planning was a History of the English Ruling Classes, from the Tutor period to the present, but he was baffled by the challenge of imposing

\footnotetext{
150 Trevor-Roper (2015) 78; see below. In his 'Apologia' Trevor-Roper (1974: 402) admitted that as a student 'the Roman poets, apart from Catullus and Lucretius, did not then appeal to me: Virgil and Horace, who now seem to me the most perfect poets of all, are perhaps too calm, too mature, as well as too exquisite, for a juvenile taste'.

151 Trevor-Roper (2015) 54.

152 Trevor-Roper (2015) 212; cf. 54.

${ }^{153}$ Cf. too Trevor-Roper (2015) 132.

154 Trevor-Roper (2015) 213.

155 Trevor-Roper (2015) 213.

156 Trevor-Roper (2015) 213. Trevor-Roper did draw intellectual inspiration from the 'life of the people': in discussing style, he appreciated the importance of drawing on experience of the natural world and of 'low life in taprooms and circuses and at earthstoppers' dinners' (122).
} 
form on 'so vast a subject'. ${ }^{157}$ In the following decade he would struggle with the problem of marrying narrative and social analysis in writing a study of the English Puritan revolution. ${ }^{158}$ Trevor-Roper would put both projects aside, defeated in part by the problem of form

In so self-conscious an enterpise as the wartime notebooks - he even compiled an index to them - Trevor-Roper's classicism helped to elevate pleasurable moments in the country and to stimulate his cultivation of style. Although he sustained his historical interests during the war, he had no opportunity for historical writing. After the war he resumed it. Henceforth his classicism, which in wartime had found mainly a literary expression, would work its way into his writing on other subjects and supply formidible analogical and metaphorical weaponry. His correspondence, for example, abounds with Latinate ornamentation, and classical allusion, and quotation. ${ }^{159}$ This artificiality is particularly discernible in his letters to Bernard Berenson and to Wallace Notestein (1878-1969), the Yale historian. Oxford has 'umbratile cloisters' and 'gently susurrating coulisses' ${ }^{160}$ In a vivid vignette about the 'great siege of Floors castle', the unsuspecting Duchess of Roxburghe used an 'armigerous paperknife' to slit open a letter from her husband (the 'morose and boorish spouse' sitting with her at breakfast) that demanded she leave the castle immediately. ${ }^{161}$ In one letter to Notestein Trevor-Roper reveals a sensitivity to form which betrays a classical presence, perhaps unintended. On holiday at Beaulieu-sur-Mer in March 1959, he

\footnotetext{
${ }^{157}$ Trevor-Roper (2015) 218; cf. 150-53. For this project see also Worden (2007) 255-57; Ghosh (2011) 485.

${ }^{158}$ In a letter asking J. H. Elliott to read an unfinished draft of the book, Trevor-Roper exclaimed, 'I cannot find a satisfactory form or ending for it': 4 February 1961 (Soc. Dacre 1/3/14). See also TrevorRoper to B. Berenson, undated (early January 1958) = Trevor-Roper (2006) 249-50; 3 December 1958 = Trevor-Roper (2006) 262-63; Worden (2007) 263-67.

${ }^{159}$ E.g. classical quotations: Trevor-Roper (2006) 12 (Lucan), 14 (Lucretius), 19 and 177 (Horace), 24 (Homer), 34 (Terence), 60 and 65 (Calimachus), 74 (Virgil), 96 (elder Pliny); Trevor-Roper (2014a) 244 (Aelius Donatus), 290 and 381 (Herodotus). Similes: Trevor-Roper (2006) 15 ('as obsolete as Cambyses'), 47 ('like Epicurus' gods'), 76 ('like the ancient river Alpheus'), 100 ('like Aeneas'), 232 ('like Egeria to King Numa Pompilius'), 288 ('like an Epicurean sage'); Trevor-Roper (2014a) 3 ('like the infant of Saguntum'). Classical rhetorical figures: Trevor-Roper (2006) 293 (recusatio), 300 (anaphora).

160 Trevor-Roper to Berenson, 5 February $1953=$ Trevor-Roper (2006) 109; 28 December, $1955=$ Trevor-Roper (2006) 187. See also 'funambulatory course' ( 2 September $1953=$ Trevor-Roper (2006) 124). Remarking on Trevor-Roper's use of 'fuliginous' (of the air of Glasgow), 'umbratile', and 'funambulatory', Keith Thomas (2007: 53) observed the 'ironic contrast between the Latinate grandeur of [the] language [of the letters] and the triviality of their subject matter (mostly Oxford gossip)'. For an example of Latinate vocabulary from Trevor-Roper's journalism cf. his description of Oxbridge colleges: 'There are depths below depths, caves within caves, exquisite anfractuosities carved and incrusted by time and the slow tortuous operation of their inhabitants' (Trevor-Roper (1989)).

${ }^{161}$ Trevor-Roper to Berenson, 22 September 1953 = Trevor-Roper (2006) 127. Cf. also 'disponge' (128).
} 
wrote to Notestein with a pun on his name of the 'not-too-serious books' he was reading and the 'not-too-serious letters' he was writing. ${ }^{162}$ The pose of semiplayfulness does little to disguise the care Trevor-Roper took in crafting his letters which evokes the disingenuous programmatic claims of the younger Pliny to have collected together letters that were written merely paulo curatius, 'with a little more care than usual', and to have paid no mind to their arrangement. ${ }^{163}$ Notestein discerned the literary brilliance of Trevor-Roper's letters, and, like a good Plinian correspondent, encouraged their publication. ${ }^{164}$

Recording his intellectual debt to Samuel Butler in his wartime notebooks, Trevor-Roper described contemporary classical scholarship with a river metaphor that was characteristic of this 'passionate Potamolator': 165

\section{Classical Scholarship}

That great river which once rolled through the life of Europe, fertilising so many generations, and working so many mills and factories for the enrichment of the human mind, has now, like Oxus, lost itself in stagnant shallows; and dreary pundits, like wading birds, peck and grub in it for their unappetising fare. ${ }^{166}$

Trevor-Roper's contempt for classics in a project focussed on the cultivation of his persona as an historian was not merely a triumphant assessment of current conditions that vindicated past choices: he was expressing an attitude to classical studies that shaped his development as an historian. The connection is made explicit in his inaugural lecture of November 1957 as Regius Professor of Modern History in the University of Oxford. As in his later 'Apologia' he had Eduard Fraenkel in his sights.

In a lecture that advocated making history accessible to lay audiences TrevorRoper argued that the humanities are different from the sciences because the sciences

\footnotetext{
${ }^{162}$ Trevor-Roper to W. Notestein, 7 March 1959 = Trevor-Roper (2014a) 68.

${ }^{163}$ Epist. 1.1 frequenter hortatus es ut epistulas, si quas paulo curatius scripsissem, colligerem publicaremque. collegi non seruato temporis ordine (neque enim historiam componebam), sed ut quaeque in manus uenerat. superest ut nec te consilii nec me paeniteat obsequii. ita enim fiet, ut eas quae adhuc neglectae iacent requiram et si quas addidero non supprimam. uale. Cf. Whitton (2013) 12.

${ }^{164} \mathrm{~W}$. Notestein to Trevor-Roper, 22 January $1951=$ Trevor-Roper (2006) 281.

165 Trevor-Roper (2015) 131, 198; cf. 27, 96-7, 255, 283.

166 Trevor-Roper (2015) 35.
} 
require a specialised dialogue between professionals: it is not imperative for their existence that they appeal or communicate to the laity. ${ }^{167}$ The humanities are quite different. They 'owe their title to existence to the interest and comprehension of the laity', not to the training of professionals in the discipline. The value of technical specialisation in the humanities, he argued, lies wholly in its ability to make subjects clearer and more intelligible to popular audiences. A 'completer professionalism' might achieve perfect knowledge of history and literature, but the danger is that the perfect knowledge may be so fine that only its possessors may wish to possess it - to the detriment of civilised society. To illustrate the danger he invoked 'classical studies'. He dismissed the accusation that 'the study of classics', that is a classical education per se, is 'too narrow': 'I do not believe a study which was wide enough to educate Gladstone and Derby and Asquith and Curzon is too narrow for us'. The problem is specialisation:

\begin{abstract}
What has happened is not that the subject has lost its value but that a humane subject has been treated as an exact science: professional classical scholars have assumed that they are teaching only other professional classical scholars; consequently they have killed the classics. When I see a Greek Tragedy, one of the greatest works of human literature, a tragedy no longer than a single book of Paradise Lost, put out into the world with a commentary of three large octavo volumes round its neck, weighing in all nearly half a stone, I fear the poor thing will not get far: it will languish and die, die of strangulation and neglect in some corner of a forgotten bookshelf. 168
\end{abstract}

The work in question was Eduard Fraenkel's recent edition of Aeschylus' Agamemnon, 'the most detailed commentary ever devoted to a Greek book', as Lloyd-Jones would describe it. ${ }^{169}$ It was a bold allusion to a scholar at the height of his eminence. Trevor-Roper made the identification explicit in a letter to Bernard Berenson shortly afterwards:

I'm afraid my inaugural lecture has caused a good deal of mumping among the Manchester medievalists, and the former Professor of Latin, Eduard Fraenkel, a German of the most boring kind, the author of the $3 \frac{1}{2} 2$ kilo commentary on Aeschylus' Agamemnon to which I made a discreetly veiled reference, is furious. He wrote to the Regius Professor of Greek [E.

\footnotetext{
167 Trevor-Roper (1957b) $14=$ Lloyd-Jones et al. (1981) 8.

168 Trevor-Roper (1957b) 15 = Lloyd-Jones et al. (1981) 8-9. For Trevor-Roper's views on commentaries see also Trevor-Roper (1974) 410; (1991) 66-67.

${ }^{169}$ Lloyd-Jones (1982a) 255.
} 
R. Dodds] asking him, as a member of the Governing Body of Christ Church, to see that I was properly disciplined. ${ }^{170}$

Already in 1957 Trevor-Roper was publicly representing classical studies as overly specialised and Eduard Fraenkel as its living embodiment. Trevor-Roper warned historians to avoid the same pitfall and advocated rendering research accessible to lay audiences. Here they could take a more positive lesson from a different aspect of contemporary classical scholarship:

if an interest in the classics survives today, apart from subsidies they enjoy from the past, that may well be due rather to the enterprise of Sir Allen Lane and his Pelican books, where they appear, purged of otiose learning, reanimated by lay interest, than to the heavy cosseting of professional scholars. ${ }^{171}$

It was important for Trevor-Roper's argument that an outside stimulus could refresh the discipline, for he went on to express the hope that professional outsiders would continue to stimulate historical studies as they had done since the $18^{\text {th }}$ century. ${ }^{172} \mathrm{In}$ his 'Apologia' of 1973 he would name outside influences on classics that were helping to rejuvenate the discipline, and it is an eloquent point of symmetry with his inaugural lecture that Moses Finley's works, including The world of Odysseus, were by then appearing as Pelican Books. ${ }^{173}$

\section{VI}

Few now would disagree with the demands that Trevor-Roper made of classical scholars: that they should have broad intellectual horizons; should be open to methodologies from outside the discipline; should study literature in its historical context; ${ }^{174}$ and should make the fruits of their research intelligible to lay audiences. Less convincing was his rejection of the value of textual criticism. Here Lloyd-Jones was right. A long tradition of philological scholarship underpinned the editions that allowed Trevor-Roper to enjoy classical authors and historians such as Finley to use

\footnotetext{
170 Trevor-Roper to Berenson undated (mid-December 1957) = Trevor-Roper (2006) 246.

171 Trevor-Roper (1957b) 15 = Lloyd-Jones et al. (1981) 9.

172 Trevor-Roper (1957b) 19-21 = Lloyd-Jones et al. (1981) 11-12.

${ }^{173}$ The world of Odysseus was published as a Pelican book in 1962. Other works by Finley followed suit: e.g. Aspects of Antiquity; The ancient Greeks; Ancient slavery and modern ideology.

${ }^{174}$ Conversely, as an historian, he encouraged colleagues not to neglect the insight literature could give to the society that formed its background. See e.g. Trevor-Roper (1974) 407-08; (1976) 7.
} 
literary texts to illuminate ancient societies, and philological methodologies are required to render useful new discoveries on vellum, papyri, stone, and bronze. Trevor-Roper's maneovre of celebrating the work of Dodds and Finley in opening up new vistas in the study of antiquity merely sidestepped the fate of classical philology by moving the emphasis to historical studies. He disparaged philologists and editors, and had no positive advice for them.

Trevor-Roper was, nonetheless, deeply indebted to the philological tradition that he mocked. It was an imersion in the language of the classical world, not in its history, that had brought him to love Latin and, still more, Greek literature. His schooling created habits and pleasures of reading that would never leave him. He read Sophocles' Oedipus Coloneus for the first time during the Christmas vacation of 1962/63 as part of a resolution to read and reread the Greek tragedians: 'I must go quietly through the whole canon, even if I fall behind in the latest historical periodicals' ${ }^{175}$ Homer, Virgil, and Horace were his constant companions. As Master of Peterhouse he had a copy of Virgil bound as a prayer book for reading during Chapel services. ${ }^{176}$ In 1988, not long after retiring from Peterhouse, when asked on the BBC Radio 4 programme Desert Island Discs to name a book other than the Bible and Shakespeare that he would wish to have on his island, he replied, 'the works of Virgil' on the ground that they were infinitely rereadable. His choice led to an invitation to become President of the Virgil Society for $1989 / 90 .{ }^{177}$ His Presidential address demonstrated his commitment to reading texts in their historical and intellectual contexts. Above all it illustrated his sensitivity to literary style. In saluting Virgil as the high point of Latin poetry, he asked what quality had enabled him to assert his 'invincible superiority'. The answer was style: 'where else in world literature can we find such economy, such flexibility, of language, such supreme artistry in its manipulation, such musical sensitivity, such sustained elevation'. ${ }^{178}$ For Trevor-Roper true appreciation of Virgil rested on knowledge of Latin. At the end of his address he offered Dryden's warning of 'the sacrilege of translating Virgil' as a clear lesson for 'lovers of literature' : 'we must not allow the study and knowledge of

\footnotetext{
175 'Resolutions' on p. 3 of a notebook entitled '1963' that commences 'Xmas Vacation 1962-3' (Soc. Dacre 13/29). For this notebook cf. Robertson (2009) 1402-03; Robertson in Trevor-Roper (2010) x; Ghosh (2011) 489 n.78.

${ }^{176}$ Worden (2007) 249. For Trevor-Roper at Peterhouse see Pattenden (2002/03); Tulloch (2002/03); Sisman (2010) 451-74.

${ }^{177}$ M. M. Willcock to Trevor-Roper, 19 April 1989 (Soc. Dacre 2/1/63).

${ }^{178}$ Trevor-Roper (1991) 66.
} 
the Latin language to die'. ${ }^{179}$ With that, at least, Lloyd-Jones would have strongly agreed.

Appendix

Although Lloyd-Jones agreed with Trevor-Roper's portrait of Housman (cf. above p.18), he did correct him over Housman's supposed opposition to Fraenkel's election to the chair of Latin at Oxford. Trevor-Roper had claimed that when it was rumoured that Fraenkel would be elected to the chair, 'Housman wrote a magisterial letter of protest' that he 'should not be elected at Oxford since he was the only scholar fit to succeed himself at Cambridge'. ${ }^{180}$ Lloyd-Jones responded that 'Housman's letter to The Sunday Times was not to protest at Fraenkel's election, but to silence an ignorant critic of it; certainly he said he was sorry that F. would not succeed him at Cambridge, but not in that letter...; Housman was an elector, to the Oxford chair, and actively supported Fraenkel'. ${ }^{181}$ Trevor-Roper replied in turn that D. L. Page had told him that Housman had written thus in a letter prior to Fraenkel's election. ${ }^{182} \mathrm{He}$ adjusted the text of the version of his address that he published in The Spectator to read '...Housman (I was told) wrote...', but the version printed in Didaskalos returned to the original.

Housman, who was not an elector to the chair at the time of Fraenkel's election, ${ }^{183}$ supported Fraenkel with a testimonial that concluded, 'I cannot say sincerely that I wish Dr Fraenkel to obtain the Corpus Professorship, as I would rather that he should be my successor in Cambridge', ${ }^{184}$ and on his election Housman wrote to Fraenkel on 13 December 1934 with congratulations that opened with the comment that 'we shall be sorry to lose you from Cambridge'. ${ }^{185}$ If Housman echoed his testimonial in private correspondence, it has not survived. His high estimation of Fraenkel was repeated in a letter to The Sunday Times of 23 December 1934 in which

\footnotetext{
179 Trevor-Roper (1991) 74.

180 Trevor-Roper (1974) 405.

${ }^{181}$ H. Lloyd-Jones to Trevor-Roper, 4 June 1973 (Soc. Dacre 2/1/36).

182 Trevor-Roper to H. Lloyd-Jones, 7 June 1973 (Soc. Dacre 2/1/36).

183 A. E. Housman to E. Fraenkel, 12 November 1934 = Burnett (2007) 2.447.

${ }^{184}$ See Diggle and Goodyear (1973) $3.1277=$ Burnett (2007) 2.448.

185 This letter is published for the first time at Oakley (2009) 84.
} 
he wrote, beginning with a quotation from the critic he was called on to silence, “"Herr Fraenkel is a Latinist of European reputation." I do not know who the other candidates were, but they cannot have been Latinists of European reputation; for no Englishman who could be so described was young enough to be eligible'. ${ }^{186}$

\section{Bibliography}

Bagehot, W. (1858) 'William Cowper', Estimates of some Englishmen and Scotchmen, London, $46-103=(1879)$ 1.255-307.

(1879) Literary studies, London.

Beard, M. (2013) Confronting the classics, London.

Briggs, W. W. and Calder, W. M. (eds) (1990) Classical scholarship: a biographical encyclopedia, New York-London.

Burnett, A. (ed) (2007) The letters of A. E. Housman, Oxford.

Butler, S. (1913) The humour of Homer and other essays. Ed. R. A. Streatfield, London.

- (1934) Further extracts from the note-books of Samuel Butler. Ed. A. T. Bartholomew, London.

- (2003) The authoress of the Odyssey: where and when she wrote, who she was, and use she made of the Iliad, and how the poem grew under her hand. Introduction by T. Whitmarsh (1897), Bristol.

Butterfield, D. and Stray, C. (eds) (2009) A. E. Housman: classical scholar, London.

Currie, R. (1994) 'The arts and social sciences, 1914-1939', in Harrison (1994) 10938.

Diggle, J. and Goodyear, F. R. D. (eds) (1973) The classical papers of A. E. Housman, Cambridge.

Finley, M. I. (1966) 'Unfreezing the classics', TLS 7 April 1966, 289-90.

- (1978) The world of Odysseus. Second revised edition, Harmondsworth.

- (1982) 'Modern prejudice', London Review of Books, 2 December 1982, 3-4

- (2002) The world of Odysseus. Introduction by S. Hornblower. Folio Society edn, London.

- and Hopkins, K. (2014) 'Keith Ho pkins interviews Sir Moses Finley:

October 1985 transcript', AJPh 135, 179-201.

\footnotetext{
${ }^{186}$ Burnett (2007) 2.456-57.
} 
Ghosh, P. (2011) 'Hugh Trevor-Roper and the history of ideas', History of European ideas 37, 483-505.

Gretton, J. (1973) 'Classics teachers "fighting for our lives", TES 3026 (26 May) 8.

Hainsworth, J. B. (1979) review of M. I. Finley, The World of Odysseus ${ }^{2}$, Classical Review 29, 135.

Harris, W. V. (ed.) (2013) Moses Finley and politics, Leiden-Boston.

Harrison, B. (ed.) (1994) The history of the University of Oxford. Volume VIII: the twentieth century, Oxford.

Housman, A. E. (1926) M. Annaei Lucani belli ciuilis libri decem, Oxford. (1931) 'Praefanda', Hermes 66, 402-12 = Diggle and Goodyear (1973) 3.1175-1184.

Kenney, E. J. (ed.) (1990) Apuleius: Cupid and Psyche, Cambridge.

Kidd, C. (2011) 'The Warren commission and the dons: an Anglo-American microhistory', Modern intellectual history 8, 411-34.

Lloyd-Jones, H. (1981) 'Remarks on the Homeric question', in Lloyd-Jones et al. (1981) 15-29 = Lloyd-Jones (1990) 3-20.

(1982a) Blood for the ghosts: classical influences in the nineteenth and twentieth centuries, London.

- (1982b) Classical survivals: the classics in the modern world, London.

- (1990) Greek epic, lyric, and tragedy: the academic papers of Sir Hugh

Lloyd-Jones, Oxford.

- and Pearl, V., Worden, B. (eds) (1981) History and imagination: essays in honour of H. R. Trevor-Roper, London.

Naiden, F. S. and Talbert, R. (2014) 'Introduction [to the special issue: Moses Finley in America: the making of an Ancient Historian]', AJPh 135, 167-78.

Nisbet, R. (2007) 'The study of classical literature at Oxford, 1936-1988: I. Half a century of classical research at Oxford', in Stray (2007) 219-25.

Oakley, S. P. (2009) 'Housman, Lucan and Fraenkel', in Butterfield and Stray (2009) 65-94.

Pattenden, P. (2002/03) 'Master of Peterhouse', Peterhouse annual record, 205-12.

Pinney, T. (ed.) (1974-81) The letters of Thomas Babington Macaulay, Cambridge.

Reeve, M. D. (2009) 'Dust and fudge: manuscripts in Housman's generation', in Butterfield and Stray (2009) 139-52.

- (2011) Manuscripts and methods: essays on editing and transmission, Rome. 
Robertson, J. (2009) 'Hugh Trevor-Roper, intellectual history and "The religious origins of the enlightenment", English Historical Review 124, 1389-1421.

Russell, D. (2007) 'The study of classical literature at Oxford, 1936-1988: II. Times change', in Stray (2007) 225-38.

Saumarez Smith, J. (2014) 'Hugh Trevor-Roper's library', The book collector 63, 427-32.

Sharwood Smith, J. E. (1974) 'Editorial', Didaskalos 4, 391-92.

Sisman, A. (2010) Hugh Trevor-Roper: the biography, London.

Stanford, W. B. (1957) 'The Homeric World', Classical Review 7, 199-201.

Stray, C. (1998) Classics transformed: schools, universities, and society in England, 1830-1960, Oxford.

- (ed.) (2007) Oxford classics: teaching and learning 1800-2000, London.

- (2015) 'Eduard Fraenkel: an exploration', Syllecta Classica 25, 33-73.

- (forthcoming) 'Thomas Gaisford: Legion, legend, lexicographer'.

Stray, C., Pelling, C., and Harrison, S. J. (eds) (forthcoming) Commemorating E. $R$. Dodds. Oxford.

Thomas, K. (2007) ‘A highly paradoxical historian', The New York review of books 54.6 (12 April), 53-57.

Todd, R. B. (2004) The dictionary of British classicists, Bristol.

Tompkins, D. P. (2013) 'Moses Finkelstein and the American scene: the political formation of Moses Finley, 1932-1955', in Harris (2013) 5-30.

Trevelyan, G. O. (1876) Life and letters of Lord Macaulay, London.

Trevor-Roper, H. (1936) 'Homer unmasked!', The Oxford magazine 30 April, 514-17.

- (1939) 'William Somervile: the poet of the chase', Country Life 10 June, 614-15.

- 'The world of Homer', New statesman, 14 July, 45-6 = (1957a) 6-11.

- (1957a) Historical essays, London.

- (1957b) History: professional and lay: an inaugural lecture delivered before the University of Oxford on 12 November 1957, Oxford = Lloyd-Jones et al. (1981) 1-14.

- (1974) 'Apologia transfugae', Didaskalos 4, 393-412.

- (1976) Princes and artists: patronage and ideology at four Habsburg courts 1517-1633, London.

- (1989) 'The Peterhouse Effect', The Independent magazine 9 December, 16. 
- (1991) 'Why Virgil?', Proceedings of the Virgil society 20, 60-75.

- (2006) Letters from Oxford: Hugh Trevor-Roper to Bernard Berenson. Ed.

R. Davenport-Hines, London.

- (2010) History and the enlightenment. Ed. J. Robertson, New HavenLondon.

- (2014a) One hundred letters from Hugh Trevor-Roper. Ed. R. DavenportHines and A. Sisman, Oxford.

- (2014b) The secret world: behind the curtain of British intelligence in world war II and the cold war. Ed. E. Harrison, London

- (2015) The wartime journals (corrected edition), ed. R. Davenport-Hines, London.

Tuckwell, W. (1907) Reminiscences of Oxford, London.

Tulloch, R. (2002/03) 'Dacre the dictator', Peterhouse annual record, 212-13.

West, S. (2007) 'Eduard Fraenkel recalled', in Stray (2007) 203-18.

Whitmarsh, T. (2002) 'What Samuel Butler saw: classics, authorship and cultural authority in late Victorian England', PCPS 48, 66-86.

Whittaker, C. R. (1997) 'Moses Finley 1912-1986’, PBA 94, 459-72.

Whitton, C. (2013) Pliny the younger: Epistles book II, Cambridge.

Wilson, N. G. (2011) 'Peter Hugh Jefferd Lloyd-Jones (1922-2009)', PBA 172, 21529.

Worden, B. (2007) 'Hugh Redwald Trevor-Roper (1914-2003)', PBA 150, 247-84. 